\title{
Entre Princípios e Regras: Cinco Estudos de Caso de Ação Civil Pública*
}

\author{
Luiz Werneck Vianna \\ Marcelo Baumann Burgos
}

\section{APRESENTAÇÃO}

\begin{abstract}
A democracia brasileira é, hoje, um rico laboratório de práticas e de instituições representativas, a essa altura responsável por mudanças sem paralelo na história das relações entre o seu Estado e a sociedade civil e na das relações entre os seus sistemas político, econômico e social. Tais mudanças, contudo, não têm importado uma ruptura com o que se pode designar como a nossa tradição republicana. Longe disso, confirmam alguns de seus principais traços, como a valorização da esfera pública vis-à-vis a esfera privada - de que é exemplo forte o condicionamento do direito de propriedade ao princípio da sua função social - e a preservação do direito, suas instituições e procedimentos como peças-chave da pedagogia republicana. Sua novidade consiste, antes, em terem erradicado dos seus fundamentos e de suas instituições as inspirações e as práticas autoritárias que caracterizaram aquela
\end{abstract}

\footnotetext{
* Essa pesquisa, resultado de um convênio entre o Instituto Universitário de Pesquisas do Rio de Janeiro - IUPERJ e a Associação dos Magistrados do Estado do Rio de Janeiro, foi realizada no âmbito das atividades do Centro de Estudos de Direito e Sociedade CEDES do IUPERJ, tendo recebido apoio institucional da Financiadora de Estudos e Projetos - Finep. A pesquisa contou com a dedicada e qualificada colaboração de Karen Costa Soares, Marina Pombo de Oliveira e Michelle de Moraes Ferraz, alunas de Ciências Sociais do Departamento de Sociologia e Política da Pontifícia Universidade Católica do Rio de Janeiro - PUC-Rio.
}

DADOS - Revista de Ciências Sociais, Rio de Janeiro, Vol. 48, nํ4, 2005, pp. 777 a 843. 
tradição ao longo do processo de modernização burguesa, na forma imposta pela experiência republicana que nos veio da Revolução de 1930, ora atenuadas, como no período 1945-64, ora dramaticamente agravadas, como no ciclo subseqüente do regime militar.

Com efeito, esse foi o sentido da Carta de 1988 em sua opção de reinterpretar, sob clave democrática, a tradição republicana brasileira, de resto favorecida pela circunstância do atraso com que nos chegaram as notícias de além-mar sobre a situação falimentar do paradigma da social-democracia para os fins de uma gestão harmoniosa do capitalismo. Como é sabido, desde então, sucessivas emendas constitucionais têm expurgado a Constituição, fiel em sua origem à matriz social-democrata predominante entre seus legisladores, das disposições que previam um papel organizador para o Estado em matéria econômica.

Contudo, se essa adaptação à onda neoliberal concedeu à dimensão sistêmica da economia uma autonomia inédita na moderna ordem burguesa brasileira, foi modulada por um contexto em que são mantidas as vigas mestras da Carta de 1988, entre as quais a concepção de que a nação conforma uma comunidade solidária - tópico crucial à nossa tradição republicana -, a valorização da esfera pública como instância de promoção de integração social e o papel ético-pedagógico atribuído ao Direito, suas instituições e procedimentos na formação da cidadania e do civismo. Tal tradição, como notório, tem uma de suas raízes na fórmula de organização do mercado de trabalho sob a jurisdição da Consolidação das Leis do Trabalho - CLT e do judiciário trabalhista, que, aliviada da sua carga autoritária original, se encontra preservada em nossa vida institucional. O sinal mais forte disso está na criação constitucional do Ministério Público como guardião da vontade geral expressa pelo legislador constituinte, incumbindo-lhe "a defesa da ordem jurídica, do regime democrático e dos interesses sociais indisponíveis" (art. 127 da Constituição Federal).

A par dessa releitura da nossa tradição republicana, a Carta afirmou a herança e as instituições do liberalismo político - igualmente com raízes seguras entre nós -, recortando com nitidez os direitos civis da cidadania e estabelecendo a configuração de uma plena democracia política, com a criação de mecanismos necessários a uma gestão pública orientada para a eficiência. Sob essa orientação estratégica, o constituinte previu duas formas de representação, a do voto e a funcional, e 
duas formas de participação, a representativa, que se assenta no princípio eleitoral, e a direta, que compreende a iniciativa popular, o referendo, o plebiscito e a ação popular, entre outros dispositivos, mas que, salvo no caso deste último, ainda são de existência puramente retórica. O enlace da representação política com a funcional dá-se na própria jurisdição da competição eleitoral, que é confiada ao Poder Judiciário por meio dos tribunais da Justiça Eleitoral, confirmando-se, mais uma vez, em 1988, a inovação institucional introduzida em 1932.

Indicação mais recente do caráter benfazejo desse enlace está em duas medidas tomadas pela Justiça Eleitoral, que praticamente aboliram as fraudes no processo da votação: o cadastro informatizado e nacionalizado dos eleitores - que dificultou a duplicação de títulos em localidades diferentes e eliminou das listas um extenso contingente de mortos - e a urna eletrônica ${ }^{1}$.

Ao lado disso, a Lei no 9.840 , de 28 de setembro de 1999, fruto da iniciativa da Conferência Nacional dos Bispos do Brasil - CNBB, da Ordem dos Advogados do Brasil-OAB e de dezenas de entidades e movimentos da sociedade civil, viabilizou o estabelecimento de ações conjuntas entre a Justiça Eleitoral, a vida associativa e a cidadania em geral, visando à eliminação da corrupção eleitoral, inclusive no mais remoto hinterland ${ }^{2}$, o que já vem ocorrendo e deverá multiplicar-se a partir do estímulo que significou a recente premiação do magistrado que a levou à prática nas eleições de 2002 nos municípios de Alto Parnaíba e Tasso Fragoso, no Maranhão ${ }^{3}$.

Em suma, o Brasil apresenta, hoje, uma robusta democracia política, em que a quase totalidade da população adulta, incluídos os analfabetos, pode se manifestar eleitoralmente, trazendo para o interior do sistema político suas expectativas e interesses. Contudo, o modo pelo qual se realiza o financiamento das campanhas, abertas à manipulação e ao controle do poder econômico, inclusive pelos mecanismos, nem sempre visíveis, da compra de votos, mais o fato da fraqueza do nosso sistema partidário, expressa sintomaticamente no conhecido fenômeno da troca de legendas, são mazelas que tendem a minar a confiança da população nessa forma de representação.

Tal fraqueza tem permitido a montagem de um complexo sistema por meio do qual o Executivo exerce controle sobre mecanismos de cooptação dos parlamentares - o chamado presidencialismo de coalizão -, atraindo-os à sua base de sustentação congressual pelo atendimento 
de políticas públicas regionais e clientelas locais. Nesse quadro, em que pese o fato de as instituições de democracia política se encontrarem, de uma perspectiva formal, em franco processo de consolidação, a crônica dissociação entre representados e representantes, mais a evidente ultrapassagem do Legislativo pelo Executivo nas tomadas de decisão quanto a questões estratégicas para os rumos da sociedade, é de se temer o seu retraimento em um sistema fechado de procedimentos, surdo às expectativas e demandas sociais.

A gravitação do Legislativo em torno do Executivo provoca a retração da esfera pública e limita suas possibilidades de contato com o mundo da opinião. A esfera pública torna-se um espaço sob controle do Executivo e das lideranças da sua maioria congressual, que, "ao selecionarem os interesses e os valores a serem defendidos e estimulados, passam a tomar, em estilo monocrático, decisões que vinculam a todos" (Werneck Vianna, 2002:9)4. Nesse sentido, o Executivo, reforçado constitucionalmente pelo instituto das Medidas Provisórias, atuaria, em particular nas matérias sistêmicas da economia e do aparelho administrativo, segundo os moldes do padrão decisionista, legitimando-se $e x$ post, quer em razão dos resultados obtidos, quer pela chancela da maioria governamental construída, em grande parte, pela sua capacidade de cooptar os quadros do Parlamento, com a mediação da máquina e de recursos públicos.

Em um cenário assim limitado, as opiniões e o fluxo das opiniões geradas na sociedade civil não encontram caminhos para se traduzirem em vontade na esfera pública, uma vez que a agenda do Legislativo se acha sob domínio do Executivo, o qual impõe nela a supremacia dos seus objetivos estratégicos em matéria econômica. Nesse sentido, a própria política social deixa de refletir as expectativas e interesses da sociedade civil organizada, tornando-se objeto de políticas públicas assistencialistas do Estado e dos seus fins de legitimação, inclusive eleitoral. Daí que a vontade trazida das urnas, em um processo eleitoral livre e aberto à participação da população, perde sua nitidez à medida que inicia sua trajetória institucional nos caminhos da representação em razão da debilidade do sistema partidário e da ausência de nexos entre representantes e representados. Com isso, o Parlamento vê-se incapacitado de propor uma agenda própria, limitando-se a exercer mero papel fiscal sobre o que lhe chega do Executivo, naturalmente especializado nos temas da administração e da gestão da dimensão sistêmica. 
Foi esse o contexto em que a representação funcional encontrou as condições para sua emergência, concedendo-se vida aos vários institutos, criados ou revigorados pela Carta de 1988, compreendidos no seu âmbito. Assim, quando o sistema da ordem se inclinou, logo após a promulgação da Constituição, no sentido de liberar a esfera econômica do que era tido como um constrangimento à sua adequada operação, a minoria parlamentar e mais os interesses organizados na sociedade civil, compreendendo algumas corporações como a OAB e mesmo o Ministério Público, vieram a contar com a nova disciplina conferida ao controle abstrato de normas, particularmente na chamada comunidade dos intérpretes dotados de legitimidade para propor ações diretas de inconstitucionalidade junto ao Supremo Tribunal Federal - STF (Werneck Vianna et alii, 1999). Inaugurava-se, naquele contexto, o que hoje é uma nova e efetiva arena para o exercício da democracia brasileira, contando, em média, com 200 Ações Diretas de Inconstitucionalidade - Adins ao ano, em que, por provocação em boa parte da sociedade civil organizada, se aprofunda e se aprimora a interpretação constitucional.

Além desse cenário propriamente político, é no terreno da sociabilidade que, no contexto aberto pela democratização do país, a representação funcional ganhará densidade e terá reconhecido o seu papel. Após duas décadas de intensa modernização econômica - que alterou drasticamente as estruturas sociais, expulsando em massa a população rural para as cidades - levada a cabo em situação de imobilidade política e de cancelamento da vida associativa, a sociabilidade que então emerge se encontra desajustada das instituições da vida republicana, principalmente dos partidos políticos. Desajustada também dos sindicatos, os quais começam a perder substância no início dos anos 1990. Com a emergência da multidão de homens comuns, novos interesses e novas expectativas de direitos passam a se manifestar, e é a partir daí que a "oferta" dos novos institutos, presente na nova Carta, irá encontrar a sua demanda - caso que começa a se generalizar com os Juizados Especiais, mas que ganha visibilidade, também, nas Ações Civis Públicas e nas Ações Populares. O acesso à Justiça adquire, então, o status de um dos tópicos principais das políticas públicas, ocupando boa parte da agenda da mídia.

O desmonte do embrião do welfare state brasileiro, o esvaziamento das instituições da vida republicana e da vida associativa vão canalizar para o interior do Judiciário as demandas reprimidas por direitos. Os 
juízes e demais agentes do sistema passam a exercer papéis cada vez mais identificados com os de engenheiro social ou terapeuta, quando não com o de prestadores de serviços de cidadania, como nos casos conhecidos dos juízes das Varas de Infância e Juventude e das caravanas volantes dos Juizados Especiais que percorrem os rincões do país e que cumprem papéis substitutivos a serviços próprios do Estado, como o de fazer o registro civil dos cidadãos 5 . À falta de república, como na conhecida afirmação de A. Garapon (1996), o Poder Judiciário aparece como um moderno "muro das lamentações", um equivalente funcional à decaída institucionalidade do Estado de bem-estar.

Esse é o contexto de "faltas", carecimentos e de vácuo da representação política, que tem sido favorável, ao menos até aqui, à tradução em realidade da intenção do constituinte de preservar a tradição republicana brasileira de fazer do direito, seus procedimentos e instituições, uma peça estratégica do seu projeto ético-pedagógico. Experiência, decerto, facilitada por ser contínua ao tipo de jurisdição que exerceu, desde os anos 1930, sobre o mercado de trabalho e a competição política - a Justiça do Trabalho e a Justiça Eleitoral -, e porque se apresenta, na moderna democracia política brasileira, como descontínua à tradição autoritária que prosperou na maior parte de nossa trajetória republicana pela primazia que atribuiu aos interesses e expectativas de direitos da sociedade civil. Com base nos princípios e valores declarados pela Constituição como centrais à comunidade brasileira ${ }^{6}$ - entre os quais o da justiça e da solidariedade -, a sociedade, de baixo para cima, pode ser parte de uma permanente recriação do direito, partindo dos seus interesses e expectativas de direitos, quer individualmente - caso das Ações Populares ou dos seus pleitos nos Juizados Especiais -, quer coletivamente por meio de sua vida associativa, como nas Adins e nas Ações Civis Públicas. Podem, ainda, mobilizar o Ministério Público, em seu papel privilegiado de guardião da ordem constitucional, e a Defensoria Pública, agora regulamentada em âmbito nacional. A representação, enfim, generaliza-se, não mais circunscrita apenas à dimensão do voto (Rosanvallon, 2000:407).

Contudo, não há porque procurar nessa verdadeira invasão da vida republicana pelo direito e na juridificação incessante e progressiva da sociedade brasileira um pretenso ativismo do Poder Judiciário. Eles são frutos diretos da intervenção do Poder Legislativo, constituinte e ordinário, e da apropriação desenvolta que a cidadania faz deles. E nisso reside a singularidade desse laboratório social brasileiro - a juridifica- 
ção, presente in nuce na Carta de 1988, conhecerá a sua grande onda expansiva, de fato, pela obra legislativa das duas décadas seguintes, especialmente na primeira, não por acaso a que conheceu as inúmeras emendas constitucionais que liberaram a dimensão econômica. Assim, em 1989, cria-se a lei que trata dos portadores de deficiência física e a que coloca sob tutela jurisdicional os interesses dos investidores do mercado de valores mobiliários; em 1990, o Código de Defesa do Consumidor, que se demonstrou central na ampliação das Ações Civis Públicas e no adensamento do papel do Ministério Público ${ }^{7}$; ainda em 1990, o Estatuto da Criança e do Adolescente - ECA e a Lei Orgânica da Saúde; em 1993, a Lei de Proteção ao Idoso e a de Proteção das Minorias Étnicas. A essas se seguem, a Lei das Águas, em 1997, a que dispõe sobre os Planos Privados de Saúde, em 1998, o Estatuto do Idoso, em 2003, além do Estatuto da Cidade, de 2001, cujo alcance se tornou mais abrangente com os dispositivos sobre usucapião urbano que vieram à luz com o novo Código Civil, introduzindo, entre dirigentes de associações de Favelas, no Rio de Janeiro, uma inédita disseminação da linguagem do direito, seus procedimentos e instituições.

Capítulo especial desse ativismo legislativo dos anos 1990, e que abre caminho para a judicialização dos mais variados interesses metaindividuais, é o da Lei da Improbidade Administrativa, de 1992, e o da Lei de Responsabilidade Fiscal, de 2000. Com isso, o controle da administração pública fica incorporado ao sistema de proteção dos interesses difusos e coletivos, tanto podendo ser acionado pela via da Ação Civil Pública - admitida a legitimidade ativa do Ministério Público - quanto pela das Ações Populares.

A inflação do peso relativo da representação funcional lhe vem, portanto, de expressa delegação do Poder Legislativo, circunstância em tudo diversa do ativismo judicial americano, que, ademais, desconhece uma figura com o estatuto institucional do Ministério Público brasileiro (Grinover, 2001). Da perspectiva da vontade do legislador tem-se, pois, uma admissão tácita de que a liberação da economia - para se ficar apenas nos exemplos fortes da privatização dos serviços públicos, incluindo o caso dos planos privados de assistência à saúde - tem produzido efeitos que escapam à capacidade de controle dos mecanismos republicanos clássicos e da vida associativa. O controle é, então, delegado à sociedade nos caminhos abertos pela juridificação da vida social e pelos novos institutos processuais, como o dos Juizados Especiais, o das Ações Civis Públicas e do Código de Defesa do Consumidor. 
A dimensão sistêmica, isolada de comunicação com a política e o social, operando em registro quase autopoiético, vê-se, desse modo, obrigada a reconhecer "ruídos" que lhe vêm de fora e que tomam forma nas vias da representação funcional, apresentando-se socialmente pelo fenômeno contemporâneo da judicialização da política - "ruídos" como os que vêm, por exemplo, dos Juizados Especiais Cíveis do Estado do Rio de Janeiro, que conheceram, entre $1^{\underline{o}}$ de janeiro de 2002 a abril de 2004, 320 mil ações contra concessionárias de serviços públicos e agências do sistema financeiro, sendo que uma delas foi alvo de 156.877 ações, em clara indicação de que "preferem enfrentar longas brigas judiciais e pagar indenizações a melhorar o serviço prestado" ${ }^{8}$. Ou dos planos privados de saúde, que, a essa altura, já naturalizaram o processo de judicialização da sua atividade, sendo notório o fato de manter advogados em sua rede hospitalar de serviços, conhecendo-se até estudos especializados da copiosa jurisprudência sobre as suas práticas na relação com seus clientes ${ }^{9}$.

Configura-se, então, por ausência de controles republicanos na operação da dimensão sistêmica, uma judicialização dos conflitos entre cidadãos e empresas, especialmente as concessionárias de serviços públicos e serviços financeiros - os planos privados de saúde, no fundamental, estão aí compreendidos -, que, na verdade, tem-se mostrado funcional às empresas. É certo que a judicialização consiste no único sistema de defesa de que dispõe o cidadão-consumidor quando lesado em seus direitos, mas não é menos certo que ela, limitada aos casos concretos levados à Justiça, não têm tido como obstar as práticas abusivas das empresas que vendem esses serviços, quer pelas baixas penalidades nas indenizações que lhes são cominadas, quer pela morosidade da ação do Judiciário, soterrado pela expansão explosiva da litigação no país, quer, ainda, pelos ritos processuais anacrônicos que paralisam a Justiça brasileira.

Nesse sentido, visto do ângulo restritivo dos interesses afetados, a mobilização do direito, seus procedimentos e instituições por parte da sociedade e do Ministério Público operam, na maioria dos casos, em registro seletivo, já que incorporam apenas os que têm conhecimento e iniciativa para exercê-lo, e puramente defensivo. Os caminhos da judicialização da política não detêm, por si sós, o condão de democratizar o Estado e as relações da dimensão sistêmica da economia com a cidadania. Visto, porém, da larga perspectiva de como se expressa o sistema de ordem vigente no país há um outro horizonte. Em primeiro lugar, 
porque demonstra que o texto constitucional, particularmente quanto aos princípios e valores que declara, está encontrando adesão popular, confirmando-se, em suas linhas gerais, o seu projeto de fazer do direito, seus procedimentos e instituições, um instrumento ético-pedagógico. De outra parte, porque tem favorecido, em uma sociedade cada vez mais exposta à lógica e aos valores mercantis, que os ideais éticos da cultura do justo e da solidariedade encontrem um cenário público adequado à sua expressão, que pode ser o das associações de favelados em luta pela conquista do solo urbano, ou o dos sindicatos, enfraquecidos na sua capacidade de negociação, que se socorrem do Ministério Público do Trabalho em defesa dos seus direitos, ou o das Organizações Não-Governamentais - ONGs que atuam em defesa do meio ambiente e dos consumidores lesados pelas empresas.

É, portanto, pelo encontro com a sociedade que a tradição republicana brasileira, malgrado a hegemonia neoliberal dessas últimas duas décadas, tem procurado conservar e reelaborar, a partir de sua matriz de origem, a sua difícil reprodução. Todo esforço, no entanto, terá pouco alcance, ou poderá ser perdido se a agenda do justo e da solidariedade social, que começa a tomar forma topicamente nos institutos da representação funcional, quase sempre por iniciativa da sociedade civil, não encontrar comunicação com a representação política, em especial nos partidos políticos, no Parlamento e na ação do Executivo, a quem cabem traduzir, de modo universalista, essas expectativas e pretensões que vêm da cidadania.

A princípio, não devem existir obstáculos fortes a essa comunicação, inclusive porque, como já se mostrou, a representação funcional e os diplomas legais a partir dos quais ela opera derivam da obra do legislador. A dificuldade tem sido manter os poderes políticos, permanentemente às voltas com o que identificam como os "constrangimentos sistêmicos" a que estariam obrigados, irrigados pelos princípios e valores da Constituição. À falta disso, as ações civis públicas têm-se constituído em um lugar em que as regras jurídicas têm merecido uma interpretação à luz dos princípios e valores constitucionais, ampliando o sistema de defesa da cidadania e, em alguns casos, até favorecendo a aquisição de direitos novos ${ }^{10}$, na forma do que os estudos de caso, apresentados a seguir, pretendem demonstrar.

Criada por lei específica em 1985, a Ação Civil Pública foi redefinida pela Constituição de 1988 e consolidada com a aprovação de várias leis 
que constituíram o que Rodolfo Mancuso (2001) denominou subsistema dos direitos coletivos em permanente ampliação. Através delas é possível postular novos direitos, afirmar os já declarados, estabelecer limites ao mercado, controlar a atuação do poder público, reclamar contra sua omissão e denunciar atos de improbidade administrativa. Como se vê, seu escopo é bastante amplo; assim como é amplo o acesso ao instrumento, que pode ser acionado por sindicatos e associações civis, pelo poder público e pelo Ministério Público ${ }^{11}$.

Conforme demonstrado por pesquisa quantitativa realizada há cerca de três anos no Município do Rio de Janeiro, os principais temas das Ações Civis Públicas são, nessa ordem: meio ambiente (35,4\%), consumidor $(34,9 \%)$, criança e adolescente $(12,9 \%)$, políticas públicas $(7,5 \%)$, administração pública $(5,9 \%)$ e idosos (1\%) (Werneck Vianna e Burgos, 2002). Tal pesquisa, além dos resultados substantivos que aportou, tornou evidente a necessidade de estudar qualitativamente alguns casos, que, examinados em profundidade, poderiam ampliar o entendimento de aspectos inacessíveis a uma abordagem de cunho predominantemente estatístico. Dessa constatação nasceu a presente pesquisa, dedicada ao estudo qualitativo da prática das Ações Civis Públicas no Estado do Rio de Janeiro, a partir da seleção de cinco casos de diferentes campos e tipos de conflito, cujos processos judiciais já foram ou definidos ou concluídos, propiciando uma análise mais criteriosa da dinâmica neles encerrada.

A coleção selecionada contempla as áreas de saúde pública, criança e adolescente, meio ambiente, consumidor e trabalho, e compreende quatro ações civis públicas já decididas em primeira instância e um termo de ajustamento de conduta, conduzido pelo Ministério Público. Das quatro ações, três foram propostas pelo Ministério Público e uma por associação civil. Os casos estudados são os seguintes:

- Ação Civil Pública dos medicamentos, ajuizada pelo Ministério Público Estadual, em 2002;

- Ação Civil Pública dos drogaditos, ajuizada pelo Ministério Público Estadual, em 2002;

- Termo de Ajustamento de Conduta da Ilha Grande, conduzido pelo Ministério Público Federal e Ministério Público Estadual, e celebrado em 2002; 
- Ação Civil Pública do leasing, ajuizada pela Associação Nacional de Assistência ao Consumidor e Trabalhador - ANACONT, em 1999;

- Ação Civil Pública trabalhista contra cooperativa considerada fraudulenta, ajuizada pelo Ministério Público do Trabalho, em 2000.

A análise dos casos permitirá problematizar a atuação do Judiciário e do Ministério Público, levando-se em conta ainda o problema da tensão entre a cultura tradicional e o caráter inovador dos processos, que vêm exigindo uma relação criativa dessas instâncias institucionais com a legislação, a jurisprudência e a doutrina, sob a égide da interpretação dos princípios e normas constitucionais. Permitirá, igualmente, avaliar como a sociedade e, em especial, seus setores organizados têm-se relacionado com tais institutos, o que implica considerar o problema da efetividade das decisões judiciais. Para esse fim, a análise dos casos obedecerá ao seguinte roteiro:

1. análise dos antecedentes do processo, isto é, de como a percepção do conflito social deu lugar à formulação jurídica;

2. análise da sustentação jurídica do pleito, procurando verificar de que maneira os autores das ações mobilizam o direito constitucional e outras fontes do direito, a fim de construir uma argumentação jurídica fundada na perspectiva do cidadão;

3. acompanhamento da construção da decisão, buscando perceber como o juiz lida com a demanda e confere respaldo jurídico e político à sua decisão. No caso do Termo de Ajustamento de Conduta da Ilha Grande, o mesmo vale para os promotores que o elaboraram;

4. avaliação da efetividade da decisão, levando em conta não apenas seus efeitos imediatos e tangíveis, mas também os efeitos simbólicos, incluindo sua repercussão na sociedade civil organizada e na luta por novos direitos.

Para realizar a pesquisa, foram recuperados os processos judiciais, os documentos que alimentaram a abertura de inquéritos, material de imprensa, e documentos técnicos do Poder Executivo. Além disso, foram feitas 30 entrevistas com atores direta ou indiretamente envolvidos com os casos em questão, dentre os quais juízes, promotores, defensores públicos, autoridades dos Poderes Executivo, estadual e municipal, membros dos conselhos públicos de saúde e da criança, professo- 
res universitários e lideranças de associações e sindicatos. As entrevistas foram realizadas entre novembro de 2003 e agosto de 2004.

\section{O CASO DOS MEDICAMENTOS}

Trata-se de uma Ação Civil Pública ajuizada pelo Ministério Público, em outubro de 2002, pleiteando que os Poderes Executivos do Estado e do Município do Rio de Janeiro fossem "solidariamente impelidos ao cumprimento da obrigação de fornecer, gratuitamente, medicamentos [...] àqueles que se apresentem em condição de hipossuficiência econômica" (Processo 2002.001.131891-3:27) ${ }^{12}$.

\section{I.1 - Antecedentes}

Na argumentação preliminar apresentada pelo Ministério Público, foi salientada a "notória ineficiência das ações do Estado e do Município no fornecimento de medicamentos à população", situação que teria levado a Promotoria de Cidadania a instalar, entre os meses de março e outubro daquele ano, quatro inquéritos e mais dois procedimentos administrativos para investigar a questão.

Interessa notar que, ainda na inicial do processo, o Ministério Público atribui à $5^{\text {a }}$ Vara da Fazenda Pública da Comarca do Rio de Janeiro a primeira comunicação sobre a "avalanche de ações individuais que ingressam todos os dias no Poder Judiciário, no que resultou, em 2001, no ajuizamento de mais de 200 ações individuais" (Processo I, 3). Por esse motivo, no início do ano seguinte, a Associação dos Magistrados do Rio de Janeiro enviava ofício ao Ministério Público, solicitando providências quanto à questão dos medicamentos. Paralelamente, o Núcleo de Atendimento da Fazenda Pública da Defensoria Pública informava, também em 2002, que "o número de pessoas que buscam a Defensoria Pública com o escopo de obter a assistência dos entes públicos para aquisição gratuita de remédios é de 20 a 25 pessoas diariamente, perfazendo um total de 400 pessoas por semana" (Processo I, 4).

Analisando-se a inicial do processo dos medicamentos, fica evidente que o conflito, mais tarde transformado em um problema político e administrativo, ganhou corpo através das vias do sistema judicial (Defensoria Pública, Ministério Público e Poder Judiciário) que recepcionam cidadãos e entidades da sociedade civil interessados em afirmar direitos sociais constitucionalmente assegurados. Assim, o recurso ao sistema judicial torna-se pertinente após uma prévia redefinição da 
questão social dos medicamentos, com a construção de um novo sujeito de direitos, a de portador de doenças crônicas.

Apesar de influenciado pelas conquistas sociais dos portadores do vírus da AIDs, que, já em 1988, são beneficiados por uma bem estruturada política pública de fornecimento de medicamentos, os portadores de doenças crônicas não contam com o mesmo apelo alcançado pela AIDs junto à opinião pública e às autoridades públicas, na medida em que não são percebidos como ameaça à saúde pública.

Por outro lado, desprovida de estrutura organizacional capaz de suportar um custoso processo de organização coletiva, sua luta pela afirmação de direitos não tinha como se dar pela via da mobilização social e da pressão direta junto aos poderes políticos. Daí que o caminho escolhido e estimulado pelas associações civis que representam esses segmentos tenha sido, alternativamente, o da procura individualizada do acesso judicial aos medicamentos através da Defensoria Pública, ao mesmo tempo em que se mobilizavam a mídia e o Ministério Público é o que informa o presidente da Associação de Doentes Renais Crônicos do Estado do Rio de Janeiro - ADRETERJ, uma das primeiras entidades a provocar o Ministério Público, mediante elaboração de um ofício relatando as condições irregulares da entrega de medicamentos nos pólos de distribuição do Estado.

Segundo o presidente da ADRETERJ, a mobilização desta entidade em prol de uma efetiva distribuição de medicamentos aos doentes renais crônicos inicia-se no momento em que ele mesmo, sendo um paciente transplantado, permaneceu por cerca de três meses sem receber os medicamentos.

\begin{abstract}
"Sou transplantado há seis anos e preciso de diversos tipos de medicamentos [...]. Fui por três meses em vão receber os medicamentos na Moncôrvo Filho [local do pólo de distribuição do Estado]. Eles não sabiam dizer nem uma previsão para quando teriam os medicamentos [...]. Liguei para uma amiga pessoal que era jornalista na Rádio Globo e ela passou a noticiar a situação diariamente. Depois disso, liguei para uma outra amiga que é procuradora do Estado, e ela me deu a idéia de acionar o MP, contando tudo o que estava acontecendo" (entrevista, novembro de 2003).
\end{abstract}

A obtenção de liminares no Judiciário, em geral conquistadas com a assessoria jurídica da Defensoria Pública, vai aos poucos difundindo en- 
tre os portadores de doenças crônicas a idéia de que esse é um caminho eficiente para contornar a falta de estrutura administrativa dos poderes públicos para lidar com a questão. Paralelamente, o Ministério Público estabelece uma interlocução preliminar com entidades como a ADRETERJ, o Grupo Otimismo (que lida com a questão da hepatite, em especial da hepatite $\mathrm{C}$ ), com uma outra associação de renais do Rio de Janeiro, denominada Associação dos Renais Crônicos do Rio de Janeiro-ARERJ, e com os conselhos municipais de saúde e portadores de deficiência. Como afirmou um dos membros do Conselho Municipal de Saúde: "Por diversas vezes, nós [conselho municipal] fizemos denúncias sobre a situação da ausência de medicamentos tanto para o Ministério Público, quanto para a Delegacia de Defesa da Saúde" (entrevista, janeiro de 2004).

Com base nessa interlocução, e no material coligido através da abertura de inquéritos para investigar a questão, o Ministério Público concluiu pela necessidade de se instaurar uma Ação Civil Pública, a fim de alcançar "resultado de máxima eficácia social".

\section{I.2 - A Sustentação Jurídica do Pleito}

O primeiro ponto sustentado pelo Ministério Público refere-se à sua legitimidade ativa para atuar no caso. Para tanto, fazia-se necessário demonstrar a "natureza difusa do direito à assistência farmacêutica, corolário do direito à saúde e da própria assistência terapêutica integral" (Processo I, 8). Em suas alegações, o Ministério Público recorreu ao artigo 81, inciso I do Código de Defesa do Consumidor, que estabelece que "a defesa coletiva será exercida quando se tratar de interesses ou direitos difusos, assim entendidos, para efeitos deste Código, os transindividuais, de natureza indivisível, de que sejam titulares pessoas indeterminadas e ligadas por circunstâncias de fato".

Em seguida, o autor do processo mobiliza a doutrina, valendo-se de juristas como Kazuo Watanabe, e extrai de um trabalho de Rodolfo Mancuso (2001:136-137) a seguinte definição para a noção de interesses difusos: "são interesses metaindividuais, que, não tendo atingido o grau de agregação e organização necessário à sua afetação institucional junto a certas entidades ou órgãos representativos dos interesses já socialmente definidos, restam em estado fluido, dispersos pela sociedade civil como um todo" (Processo I, 9). 
Após a argumentação doutrinária, segue-se a exposição da jurisprudência firmada pelo STJ, que já estaria "pacificada quanto à legitimação do Ministério Público para a tutela de interesses individuais homogêneos, sempre que se vislumbrar a sua relevância social" (ibidem).

Demonstrada a legitimidade ativa, passa-se a sustentar a "legitimidade passiva", ou seja, a pertinência de o Estado e o Município serem interpelados quanto à questão dos medicamentos. Como destacado no processo, a Constituição Federal, em seu artigo 23, inciso II, estabelece a "competência comum da União, dos Estados, do Distrito Federal e dos Municípios na assistência à saúde", e em suas alegações o Ministério Público sustenta que o princípio da solidariedade é o pilar estruturante do Sistema Único de Saúde - SUS, tal como estabelecido pela Lei no 8.080 / 90 - que o implantou. Em seguida, alude ao Código Civil, artigos 896 e 904, para concluir que "da solidariedade decorre que os serviços de saúde podem ser exigidos de um ou de alguns dos entes federados". E como reforço ao argumento, mobiliza o Enunciado no 7 do I Encontro de Juízes de Varas de Fazenda Pública do Estado do Rio de Janeiro, o qual fixou o entendimento de que "a responsabilidade pelo fornecimento de remédios é solidária entre o Estado e o Município onde reside o autor" (Processo I, 12). Registre-se, a propósito, que a utilização de enunciados originários de encontros de juízes como fonte de direito jurisprudencial tem sido cada vez mais freqüente, tanto na arena dos direitos coletivos, como nos pequenos conflitos individuais de massa, que tramitam sobretudo nos Juizados Especiais.

O passo seguinte na proposição do Ministério Público consistiu na caracterização do direito à saúde como um direito fundamental, mediante a mobilização do artigo $6^{\circ}$ da Constituição, que estabelece que saúde, educação, trabalho, moradia, lazer, segurança, previdência social, proteção à maternidade e à infância e assistência aos desamparados são direitos sociais. Recorreu, além disso, ao capítulo da saúde, mais especificamente ao artigo 196, que estabelece que a saúde é um direito de todos e dever do Estado, "garantido mediante políticas sociais e econômicas que visem à redução do risco de doença e de outros agravos e ao acesso universal e igualitário às ações e serviços para sua promoção, proteção e recuperação". Aspecto importante nesse passo foi a sustentação de que a norma contida no artigo 196 "não é meramente programática, já que o texto constitucional encerra um direito social que impõe a sujeitos determinados - os entes federativos indicados pelo artigo 23 da Constituição Federal - um dever correlato". A esse 
respeito, o Ministério Público mobiliza jurisprudência firmada pelo STF, quando, em voto dado pelo Ministro Moreira Alves em um Recurso Extraordinário, se sustenta que:

“Os dispositivos que tratam do direito à saúde são auto-aplicáveis e de incidência imediata, tendo em vista a prevalência do direito à saúde, corolário do direito à vida, sobre todos os demais direitos. A natureza programática destas diria respeito à estrutura funcional e organizacional, mas jamais impediria o atendimento aos cidadãos. O que se tem em jogo é o bem maior e supremo de qualquer ser humano e não interesses patrimoniais" (R.E, no 264.269-0/24/11/2000).

Na conclusão do argumento, o Ministério Público declara que, uma vez caracterizado o "direito à saúde como um direito fundamental, resta clara a sua auto-aplicabilidade, uma das mais marcantes características desta categoria jurídica, expressamente reconhecida pelo artigo 5 o,$\S 1$ o , da Constituição, que estabelece que 'as normas definidoras dos direitos e garantias fundamentais têm aplicação imediata'".

A relevância dessa discussão doutrinária para a questão da cidadania parece evidente, indicando ademais que a atuação do Ministério Público no domínio da Ação Civil Pública tem estimulado a elaboração de novas interpretações do direito constitucional, abrindo passagem para a tese da auto-aplicabilidade de direitos sociais como o do acesso à saúde, através de uma criativa articulação entre direito constitucional e infraconstitucional, princípios e regras, doutrina e jurisprudência - incluindo os enunciados coletivos firmados pelos juízes. Daí que a batalha argumentativa que ocorre na arena das ações coletivas constitua, em si mesma, capítulo singularmente relevante para o avanço da fronteira da democracia no país, pois, no interior dos conflitos coletivos judiciais, estaria em andamento uma tendência, ainda discreta, de reinterpretação do direito material, tendência essa que flui nas vias criadas pela chamada revolução processual, e que tem por parâmetro o direito constitucional. E nesse novo entendimento do direito sobressai o foco no cidadão, e não no Estado.

\section{I.3 - A Construção da Decisão Judicial}

No dia 31 de outubro - 14 dias após o ajuizamento do processo - o juiz da $8^{a}$ Vara de Fazenda Pública convocou o Ministério Público, a Defensoria Pública e as Secretarias de Saúde de Estado e município para uma audiência, que resultaria na assinatura de um acordo entre os dois en- 
tes do Poder Executivo para a criação de uma "Central de Atendimento para os Necessitados de Medicamentos", cuja finalidade seria a de "viabilizar o fornecimento do medicamento necessário ao paciente, a fim de evitar a propositura de ações judiciais pedindo remédios". Acordou-se, também, que a referida Central teria por público-alvo "os necessitados encaminhados pelo Ministério Público, Defensoria Pública, Escritórios Modelos das Universidades do Rio de Janeiro, e demais entes de assistência judiciária gratuita" (Processo I, 32). O acordo entre Estado e município tinha por objetivo, portanto, a criação de uma dinâmica de encaminhamento dos pacientes para uma instância administrativa comum, evitando o ingresso da ação no Tribunal.

No acordo, assinado pelas partes e homologado pelo juiz, estabeleceu-se ainda que Estado e município "juntarão aos autos uma listagem dos medicamentos abrangidos pela presente ação que incumbe a cada qual dentro da divisão de atribuições do SUS" (Processo I, 33). A assentada fixou um prazo de 30 dias para a instalação da Central.

Ato contínuo, o juiz deferiu o pedido, destacando em sua decisão o entendimento pacífico a respeito da auto-aplicabilidade do artigo 196 da Constituição, tanto na doutrina quanto na jurisprudência, "pois tratando-se de garantia ao direito fundamental da dignidade da pessoa humana, sua auto-aplicabilidade decorre do comando do art. $5^{\circ} \& 1^{\circ}$ da Magna Carta" (ibidem). E, para delimitar o alcance de sua decisão, arrolou nove itens que comporiam seu escopo, limitando o efeito da decisão para "aqueles que não podem adquirir os medicamentos por seus próprios meios", os quais "poderão aderir ao pólo ativo da presente ação" (ibidem).

Como se viu, a decisão judicial foi tomada a partir da mobilização das partes envolvidas e deu lugar à formulação consensual de uma nova política pública. A defensora pública que participou da audiência de negociação observou que a idéia da criação de uma central única de medicamentos não partiu de uma pessoa especificamente. Ao contrário, tal idéia surgiu na própria reunião (assentada), através de sugestões das partes para uma melhora da situação caótica em que se encontrava a distribuição de medicamentos. "A idéia da Central não chegou pronta na reunião, mas foi sendo construída. Achei a proposta da Central ótima. Ela traria mais racionalidade à distribuição de medicamentos, evitando idas e vindas dos pacientes aos postos de distribuição de medicamentos" (entrevista, dezembro de 2003). 
Igual impressão foi manifestada por um dos promotores presente naquela audiência: "A central surgiu como proposta dentro da reunião, onde [sic] todos expuseram sua situação e dificuldade. Por isso, a proposta me pareceu ser ainda mais interessante" (entrevista, dezembro de 2003).

Nenhuma entrevista a esse respeito foi mais reveladora do que a realizada com o próprio juiz que conduziu a negociação. Após salientar que as ações coletivas controvertidas como essa representam alto risco para o juiz, uma vez que é da sua lógica conduzir o Judiciário a um conflito aberto com o Executivo, ponderou que eventuais conflitos dessa natureza, se mal administrados, podem gerar situações-limite, nas quais não restaria ao Judiciário alternativa ao pedido de prisão de autoridades públicas - o que, além de desgastante, segundo o entrevistado, traria poucos resultados práticos. Ele entende que, por isso, esse tipo de ação acaba mobilizando a presidência do Tribunal de Justiça e a associação estadual de magistrados, ambas preocupadas com suas repercussões. Em casos como esse, pondera o juiz, "é melhor construir a decisão de forma negociada": "Chamei todos os componentes para uma decisão factível e operacional [...]. A construção da central foi uma idéia dali do momento, seria um acordo para ser cumprido espontaneamente. Então eu mandei que eles [representantes do Estado e do Município] assinassem uma carta de intenções com prazos determinados e juntamente emiti a liminar" (entrevista, abril de 2004).

Foi também com base na negociação com as partes que a tese jurídica da solidariedade entre os entes da federação, sustentada pelo Ministério Público, encontrou ressonância concreta, já que a prefeitura dispunha de mais recursos para destinar à saúde do que o Estado: "Chamei os dois Secretários [Estado e município] e perguntei o que podiam fazer para melhorar a situação. O Estado disse ter uma verba para a saúde de $\mathrm{R} \$ 700.000,00$ (setecentos mil reais), e o município disse ter uma verba de quase um bilhão de reais" (idem).

Apesar de terem assinado o acordo nos termos acima descritos, Estado e município viriam a apresentar recursos contra a liminar deferida pelo juiz, nas quais admitem o dever de fornecer gratuitamente medicamentos à população, mas questionam o alcance de sua competência.

Na réplica elaborada pelo Ministério Público, é reiterada a natureza singular do direito à saúde como um direito fundamental e, portanto, auto-aplicável, repondo-se a tese da solidariedade entre os entes da fe- 
deração, já defendida na inicial do processo. Em seguida, o Ministério Público assevera que "enquanto defensor de interesse difuso de amplíssima relevância social [...] propõe postura ativista, superado o falso dilema entre segurança e celeridade, afastando-se o mal do 'formalismo lento e maquinoso'". Em outra passagem, volta a defender seu próprio ativismo e a reclamar do Judiciário postura similar:

“Uma nova postura deve ser adotada pelo MP e pelo PJ, não sendo viável aguardarem-se reformas legislativas - que nem sempre correspondem às expectativas iniciais. Cabe aos aplicadores das leis hoje vigentes terem a coragem de proceder à releitura evolutiva destas, recolocando-as no contexto atual, afastando teses e óbices por demais ultrapassados, assumindo posição ativa" (Processo I, 105).

Através dessa sustentação jurídica, o Ministério Público pretende estar defendendo o ponto de vista do cidadão, fazendo avançar o compromisso do Estado com a sociedade, o direito e as arenas jurídicas entendidas como vias privilegiadas de afirmação da cidadania:

“Ecoa no Poder Judiciário e no Ministério Público o clamor social por acesso à Justiça, não como fim em si mesmo, mas como meio de realização prática de direitos. No mesmo passo, vozes ressonantes de nossa doutrina anunciam que o Direito - como um todo, e não apenas seu ramo processual - há de atender a este chamado, tornando-se não obstáculo, mas um meio de se garantir a consecução de tal desiderato comunitário, somente assim justificando sociologicamente sua existência" (ibidem).

Àquela altura, a batalha de argumentos jurídicos já se fazia acompanhar de uma crescente interlocução entre as instituições judiciais e indivíduos ou entidades ligadas à questão. Como lembra o juiz do caso: "Tivemos que nos preparar pra receber todo dia gente aqui batendo na porta e perguntando: - então doutor, o Estado ainda não respondeu, não tem remédio lá" (entrevista, abril de 2004).

Ainda de acordo com o juiz, a pressão exercida nessa fase foi significativa, assumindo importância psicológica, moral e política. "Fizeram uma espécie de 'panelaço' na minha porta. Por onde eu andava vinha alguém querendo falar comigo. Eles fizeram uma pressão política e, mais que isso, foi psicológica e moral [...]. Soube de pessoas que haviam falecido esperando os medicamentos, então eu fiquei numa encruzilhada entre Dom Quixote e Pôncio Pilatos"' (entrevista, abril de 2004). 
Fica evidente, aqui, a novidade do lugar social ocupado pelo juiz: alvo de pressão popular e armado de instrumentos processuais que lhe conferem poder de formular políticas públicas, o juiz vê-se alçado ao espaço político, tendo que se comportar como um engenheiro social, capaz de negociar com as autoridades, ao mesmo tempo em que precisa levar em conta os constrangimentos internos ao Tribunal, em especial a já mencionada tensão que esse tipo de ação provoca entre a presidência do Tribunal de Justiça e o chefe do Executivo. Utilizando-se a metáfora evocada pelo juiz, pode-se sintetizar a situação nos seguintes termos: caso se comporte como Pilatos, não apenas frustra a expectativa dos cidadãos que buscam o Judiciário como via de acesso ao direito, mas também arrisca a tornar o próprio sistema judicial indiferente ao avanço da cidadania; caso se comporte como Dom Quixote, corre o risco de assumir uma postura voluntarista, que pode comprometer sua imagem no âmbito do Tribunal e contribuir para desintegrar o direito.

A negociação com a prefeitura e o Estado impôs-se, assim, como a saída possível. E foi com base nela que formulou sua decisão de mérito, na qual reitera, em linhas gerais, os pontos já sustentados na decisão quanto ao pedido de liminar, confirmando inclusive o entendimento de que "são solidários os entes da Federação na realização de medidas efetivas de garantia à saúde pública [...] que deriva do art. 26, II, da C.F. [...]" (Processo I, 137).

A decisão judicial evidencia que o confronto com os princípios constitucionais também pode servir de remédio para uma das principais fontes de paralisia dos poderes públicos, que é a existência de zonas cinzentas na divisão de competências e responsabilidades entre os entes da federação. Tal como se verificou no caso dos medicamentos, essas zonas cinzentas têm sido recorrentemente utilizadas como subterfúgio para que Estado e município se esquivem diante dos usuários dos serviços públicos de saúde.

\section{I.4 - A Efetividade da Ação}

Usualmente, a noção de efetividade do direito tem sido empregada em um sentido muito literal, remetendo à idéia de que a decisão judicial resulta em um comando que deve ser imediatamente transformado em ação. Com isso, perde-se de vista seus efeitos de longo prazo sobre os valores coletivos, os quais seriam decorrentes de um lento e ainda pouco visível processo de decantação de princípios e normas constitucio- 
nais no direito comum e nos costumes e hábitos da sociedade - processo esse que, como se está procurando sustentar neste trabalho, tem sido acelerado por ações coletivas como a relatada.

No caso da ação dos medicamentos, a decisão judicial obrigava a construção de uma central única de medicamentos, tendo por objetivo promover maior racionalidade na distribuição de remédios, visto que os pacientes poderiam receber no mesmo local tanto os de competência do Estado, como os de competência do município. Todavia, o que de fato ocorreu após a decisão judicial foi a criação de uma Central de Medicamentos Municipal, cuja atribuição se resumiu quase exclusivamente a fornecer medicamentos considerados básicos. O Estado, por sua vez, demorou quase um ano para criar a sua central, o que provocou uma nova enxurrada de processos individuais pleiteando remédios. E assim, ironicamente, a central estadual, recém implantada, e ainda em caráter provisório, tem funcionado fundamentalmente como instância de administração das liminares:

"Estamos trabalhando para atender às liminares, senão mandam prender o Secretário [...]. As liminares causam uma desordem enorme aqui dentro. Temos o prazo de 48 horas para dar o remédio ao paciente [...]. O que acontece é uma quebra do orçamento por que o medicamento que é pedido para uma pessoa tem valor que daria pra comprar inúmeras outras coisas" (entrevista concedida pela superintendente da Central de Medicamentos do Estado do Rio de Janeiro, janeiro de 2004).

Com a volta das liminares individuais, cria-se um novo problema, alvo de inquietação tanto por parte do Estado quanto do município, uma vez que, com base no princípio da solidariedade, os juízes têm acolhido pedidos de liminares, em geral feitos pela Defensoria Pública, que valem para os três níveis do poder público: "Na verdade, as liminares são emitidas para o Estado, Município e União. Como a União não responde fica a cargo do Estado e da Prefeitura responder [...]. O Estado estaria mais aliviado se isso não ocorresse e pudéssemos nos ater somente aos medicamentos excepcionais" (entrevista concedida pela procuradora do Estado do Rio de Janeiro que assessora a Central de Medicamentos, março de 2004).

Na mesma linha, a superintendente da central estadual, acusa o efeito desorganizador das liminares: "Estamos distribuindo todo tipo de medicamento de ' $a$ ' a ' $z$ ' [...]. Temos pedidos aqui de medicamentos fora 
dos padrões como 'ginko-biloba', 'viagra', 'cogumelo do sol', 'AS'" (entrevista, janeiro de 2004).

E prossegue:

"Hoje, o Estado atende em torno de dezenove mil pacientes (com pedidos de medicamentos) e tem previsão para que esse número salte para quarenta mil até o final de 2005. Mensalmente, o Estado tem um gasto de nove milhões com saúde, mas nesse mês, por exemplo, [abril], só foram repassados três milhões [...]. Não existe nenhuma previsão de verba, estamos sem previsão para aumento do orçamento interno, ou seja, estamos dando nó em pingo d'água" (entrevista, abril de 2004).

Já entre os funcionários e autoridades do município, prevalece uma avaliação positiva da criação da central, como explicita o entrevistado: "A central foi super positiva; ela faz um trabalho de cadastramento dos pacientes para que o município tenha uma idéia da quantidade e de quais medicamentos devem ser comprados por mês" (entrevista concedida pelo superintendente farmacêutico da Prefeitura do Rio de Janeiro, dezembro de 2003). Entretanto, também faz coro às críticas do Estado contra os pedidos individuais de medicamentos, através de liminares: "Acredito que as ações [individuais] desorganizam a nossa administração porque muitas vezes tiramos o dinheiro de programas certos para atender a dois ou três pedidos de medicamentos caríssimos que muitas vezes nem fazem parte da listagem oficial (idem).

Mas a principal crítica da Prefeitura refere-se à tese da solidariedade, sustentada pelo Ministério Público e acolhida pelo juiz: "Esse problema da solidariedade pesa muito sobre o município porque recebemos pedidos de medicamentos caros que não são de nossa competência, mas chega a liminar com o 'cumpra-se' e nós ficamos de mãos atadas" (idem).

Um primeiro exame da questão, portanto, conduz à conclusão de que a ação coletiva aprovada pelo juiz está longe de ter equacionado a questão, trazendo, ademais, novos pontos de conflito administrativo e novos motivos de incerteza para o cidadão. Como disse a presidente da Associação de Renais do Rio de Janeiro: "Hoje estamos recebendo os remédios, mas continuo atenta porque nunca se sabe até quando isso vai seguir. A distribuição de medicamentos é sempre assim, eles entregam por um tempo e ficam sem entregar por outro" (entrevista, novembro de 2003). 
Não por acaso, a percepção das lideranças ligadas à sociedade civil quanto aos efeitos da ação coletiva mostra-se reticente, como sugerem os depoimentos a seguir: "Acho que a Ação Civil Pública não tem força política suficiente para pressionar o Estado a fazer algo" (Presidente da ARERJ). "A central está lá, mas onde estão os remédios? De que adianta Central de Medicamentos sem medicamentos?" (Presidente da ADRETERJ).

A defensora pública que atua no núcleo encarregado de examinar os pedidos de medicamentos também admite que o problema que deu origem à ação não foi resolvido: "A Ação Civil Pública surtiu como efeito a criação de uma Central de Medicamentos, que foi uma atitude de grande importância, mas ainda não foi o suficiente para a garantia do fornecimento de medicamentos" (entrevista, novembro de 2003).

Se a expectativa era a de que a Ação Civil Pública seria capaz de assegurar aos portadores de doenças crônicas, o pleno e imediato acesso aos medicamentos, a avaliação sobre a sua efetividade deverá ser, de fato, bastante desalentadora. No entanto, levando-se em conta que está em jogo um processo gradual de afirmação de um novo sujeito de direitos, parece inquestionável que, para esse resultado, a vitória jurídica constitui etapa fundamental.

É nesse sentido que vem atuando o Ministério Público ao pressionar o Estado, lançando mão inclusive de audiências públicas, este novo e importante lugar dessa arena de conflito. Nessas audiências, o promotor reúne as autoridades responsáveis pela administração pública, indivíduos diretamente interessados e representantes de entidades ligadas à questão demandada e pode, sem a mediação do juiz, mas a partir do espaço jurídico criado pela decisão judicial, pressionar o administrador a torná-la efetiva. Também nesse fórum é permitido às organizações da sociedade civil interpelarem diretamente as autoridades públicas: " $\mathrm{O}$ MP deve fazer sempre o uso da audiência pública de forma a trazer as necessidades da sociedade [...]. Ela é um instrumento nosso de monitoramento" (entrevista concedida pelo promotor de cidadania do Estado do Rio de Janeiro, outubro de 2003).

Assim, pode-se dizer que o direito constitucional é mobilizado como instrumento de luta, sendo bastante significativo o depoimento da procuradora do Estado do Rio de Janeiro, que afirma que o Estado já não tenta mais questionar a legitimidade jurídica dos pedidos de remédio feitos através de liminares: "Durante muito tempo recorremos das 
liminares, mas hoje acredito não haver mais ensejo. O que tentamos fazer é 'negociá-las' enquanto pensamos numa melhor maneira de organizar esta situação" (entrevista, março de 2004).

Se o direito é um romance em cadeia, como na conhecida metáfora de Dworkin, tem-se aqui um novo capítulo. Como disse o juiz do caso: "A ação criou um direito e isso não pode ser negado, e é lógico que o Estado vai dizer que 'bagunça' a administração, pois eles não gastavam nada com medicamentos" (entrevista, abril de 2004). E vai ainda mais longe, salientando que a ação modificou significativamente a capacidade de luta dos pacientes: "A Ação Civil Pública mudou a situação dessas pessoas, trouxe os holofotes da mídia, virou fato político e constrangeu moralmente o Secretário e o Governador" (idem).

Nessa nova dinâmica institucional, não apenas o direito jurisprudencial ganha uma importância até então estranha à tradição republicana brasileira, como também o Judiciário se vê alçado a um lugar institucional inédito. Ainda que não demonstre grande entusiasmo com o novo lugar do Judiciário, o juiz do caso em questão faz constatação similar:

"O Judiciário se transformou na caixa de ressonância da saúde pública. Os presidentes das mais diferentes associações das mais diferentes doenças queriam explicações sobre os remédios que não foram incluídos na listagem da ACP [...]. Para eles, era mais fácil chegar aqui do que na Prefeitura ou no Estado, o juiz está aqui, é fácil de tocar, mas o prefeito e governador estão fechados no gabinete" (entrevista, abril de 2004) ${ }^{13}$.

A procuradora do Estado entrevistada pela pesquisa conclui, resignada, em sentido similar: "O juiz agora tem o papel de uma espécie de administrador do estado, o qual com a caneta julga onde vão ser feitos os gastos" (entrevista, março de 2004).

\section{0 CASO DOS DROGADITOS}

Trata-se de uma Ação Civil Pública, ajuizada pelo Ministério Público em dezembro de 2002, e que tinha por objetivo obrigar a Prefeitura Municipal do Rio de Janeiro a criar um programa de atendimento ambulatorial, bem como de internação, para crianças e jovens dependentes de drogas e de álcool. Como se verá, a ação demandava do Judiciário a imposição ao poder público de uma política de assistência até então inexistente, exigindo da prefeitura a criação de pelo menos 16 leitos, distribuídos pelas cinco Áreas de Planejamento - APs em que se subdivi- 
de a cidade do Rio de Janeiro. O pedido de liminar foi acolhido e, no mérito, foi considerado procedente.

\section{II.1 - Antecedentes}

Antes do ajuizamento dessa Ação Civil Pública, o Ministério Público instaurou um inquérito, em janeiro de 1999, justificado pela promotora que o assina nos seguintes termos: "Os poucos serviços públicos existentes que se propõem ao tratamento de dependentes químicos se mostram insuficientes e inadequados para muitos jovens do Município do Rio de Janeiro, especialmente os de baixa renda, os que não querem se submeter a tratamento, os que estão em situação de rua e os que já adquiriram comprometimento psiquiátrico" (Processo n⿳o 2002.710.000. $350-0,3)^{14}$.

Já na proposição desse inquérito, o Ministério Público fundamenta sua decisão com base no Art. 227 da Constituição, que estabelece "absoluta prioridade" aos direitos da criança, e mais especificamente em seu inciso VII, § 3ํㅡㄴ que é explícito ao incluir entre os domínios do direito de proteção especial os "programas de prevenção e atendimento especializado à criança e ao adolescente dependente de entorpecentes e drogas afins". O fato de estar constitucionalizado indica que o problema da drogadição já estava visível desde a década de 1980 e, para o Ministério Público, a Constituição vinha sendo desrespeitada, conferindo a essa Ação Civil Pública uma natureza que muito a aproxima da Ação Direta de Inconstitucionalidade por omissão.

Além da Constituição Federal, o referido inquérito também se fundamenta no Estatuto da Criança e do Adolescente, em especial em seu artigo 7으, que prevê a obrigatoriedade de políticas para a proteção à criança, e em seu artigo 11, que assegura às crianças e adolescentes atendimento médico através do SUS, ou seja, do serviço público de algum ente da federação.

Cerca de três anos após aberto o referido inquérito, mais precisamente em dezembro de 2002, o Ministério Público resolve ajuizar a Ação Civil Pública, uma vez que, conforme a inicial do processo, "há anos o MP vem tentando, extrajudicialmente, e em vão, fazer com que o tratamento para estes casos seja oferecido pela rede pública de saúde", e "apesar de muitas promessas", não teria havido "avanço efetivo". 
Ainda na inicial dessa Ação Civil Pública, o Ministério Público observa que "lamentavelmente, a prática dos operadores do direito que atuam na área da infância e juventude nesta cidade demonstra que a oferta de serviços de saúde, de natureza pública, para crianças e adolescentes usuários de drogas [...] é insuficiente, para o caso dos menores que querem o tratamento, e inexistente, para o caso dos menores que não querem se tratar". E prossegue afirmando com base no inquérito que "quando os menores desejam se tratar, tratamento gratuito é oferecido apenas em regime ambulatorial, por algumas poucas entidades [nenhuma da esfera municipal], as quais, entretanto, não se fazem presentes em todas as áreas da cidade" (Processo II, 5).

Ao concluir a inicial do processo, o Ministério Público indaga: "até quando crianças e adolescentes terão que esperar o Município cumprir com o seu dever e obrigação?" (Processo II, 8).

No caso dessa ação, portanto, os principais antecedentes são o artigo 227 da Constituição e o Estatuto da Criança e do Adolescente, pois neles estão inscritas a vontade política da sociedade em conferir tratamento prioritário às questões relacionadas às crianças - em especial àquelas pobres e expostas à situação de risco social.

A história da constitucionalização da questão da criança e do adolescente começa com a mobilização da sociedade contra a Fundação Nacional do Bem-Estar do Menor-FunABEM e contra o Código de Menores, de 1979, que teria adotado a doutrina jurídica da "proteção ao menor em situação irregular", transferindo à família a responsabilidade pela criança. Opondo-se a essa doutrina, diversos segmentos da sociedade, como o Movimento Nacional de Meninos e Meninas de Rua, a Pastoral do Menor, ligada à Igreja Católica, a Associação Beneficente São Martinho, entre outras, postularam a elaboração de um novo arcabouço jurídico, que redefinisse o lugar da criança na ordem jurídica e o papel do Estado em face da questão.

Esse movimento ganhou adesões e deu lugar à campanha "Criança e Constituinte", que contou com a participação da Confederação Nacional de Bispos do Brasil, da Sociedade Brasileira de Pediatria, da Federação Nacional das Sociedades Pestalozzi, da Frente Nacional de Defesa dos Direitos da Criança e do Serviço Nacional de Justiça e Não-Violência. Em 1988, foi criado o Fórum Permanente de Entidades Não-Governamentais de Defesa dos Direitos da Criança e do Adolescente, que se mostrou decisivo na elaboração dos artigos 227 e 228 da 
Constituição. Um ano após a sua promulgação, conseguiu-se aprovar no Congresso o Estatuto da Criança e do Adolescente, sancionado em julho de 1990 pelo presidente da República.

Com o Estatuto, consolida-se a reforma jurídica do tratamento conferido à criança pela sociedade, incorporando uma certa noção de cidadania infantil ${ }^{15}$. Cria-se, assim, uma nova dinâmica administrativa e institucional, com a criação da figura do Conselho de Direitos da Criança (municipal, estadual e federal), que deveria ter composição paritária e atribuições deliberativas; dos Conselhos Tutelares, que seriam organizados nos bairros, e com atribuições protetivas e de assessoramento; das Promotorias de Infância e Juventude, que, além de desempenharem seu papel tradicional, poderiam agora mobilizar a Constituição e o ECA para respaldar ações coletivas e individuais, e das varas cível e penal do Juizado de Infância e Juventude, que tanto funcionariam como varas especializadas para cuidar de conflitos e litígios envolvendo crianças e adolescentes, como incorporariam funções executivas e tutelares, que a diferenciam do conjunto da justiça comum.

Toda essa estrutura foi criada como desdobramento da mobilização civil realizada ao longo dos anos de 1980 . Todavia, tudo indica que o processo de institucionalização das reformas alcançado com a Constituição e com o ECA surtiu um efeito paradoxal, provocando a desmobilização e a funcionarização da sociedade civil organizada - composta por ONGs e entidades filantrópicas tradicionais, que se consolidam mais como prestadoras de serviços de atendimento às crianças, em geral com recursos públicos, do que como agências voltadas para a postulação dos direitos das crianças.

Esse processo de "despolitização" foi destacado por um membro do Conselho de Direitos da Criança: "Antes do ECA, os campos eram muito definidos pois não havia parceria com o governo" (entrevista, janeiro de 2004). Em entrevista, o Juiz de Infância e Juventude fez coro às declarações da conselheira: "O movimento popular em torno da questão da criança foi muito maior antes da instituição do Estatuto da Criança. Depois de conseguido o estatuto, o movimento esvaziou" (entrevista, agosto de 2004).

Ao que tudo indica, o formato institucional de parceria entre o poder público, as ONGs e as associações fez com que se criasse uma situação geradora de efeitos perversos, na qual as entidades da sociedade civil passam a suprir a fragilidade dos serviços públicos universais de aten- 
dimento às crianças. Além disso, o próprio Conselho Municipal de Direitos da Criança tem se mostrado pouco aparelhado para se posicionar como um fórum deliberativo. Em parte, porque sua composição paritária lhe subtrai a necessária autonomia e, em parte, porque as entidades da sociedade civil que o compõem estão, como já visto, comprometidas com a execução de programas assistenciais. Mas a situação se torna ainda mais grave porque, em boa medida, a atenção do Conselho é desviada para a gestão de um fundo, composto por recursos oriundos de multas, doações e renúncia fiscal. Assim, o próprio Conselho de Direitos da Criança e do Adolescente estaria mobilizado para a execução de "programas pontuais" - a caracterização é da conselheira entrevistada-, abdicando parcialmente das funções de um conselho dessa natureza, que, no caso, deveria pressupor ampla participação no debate sobre as políticas públicas geridas pelo governo municipal.

Para a tímida atuação dos conselhos, colabora, ademais, segundo avaliação do juiz entrevistado, a falta de interesse do poder público em estruturá-los. Segundo ele, "não interessa ao governo estruturá-los, pois eles se tornariam seus próprios denunciantes"16 (entrevista, agosto de 2004).

Compreende-se, assim, porque, no caso das crianças, o Ministério Público e o Judiciário praticamente monopolizam o trabalho de postulação de ações coletivas visando a pleitear direitos. No caso específico dos drogaditos, isso fica muito evidente, pois, apesar da importância do tema, constatou-se que essa era uma preocupação praticamente solitária do Ministério Público, que contou com o acolhimento do juiz. Não surpreende, por isso, que, como admitiu um dos membros do Conselho de Direitos da Criança, "o Ministério Público mobiliza o Conselho mais do que este mobiliza o Ministério Público. Constantemente ele procura pela presidência do Conselho para estimular sua participação nos processos judiciais e na formulação de políticas públicas, mas essa articulação nem sempre se potencializa" (entrevista, fevereiro de 2004).

Compreende-se, também, a descrença demonstrada por uma das promotoras de Infância e Juventude entrevistada, em relação ao interesse da sociedade e, por conseguinte, das autoridades públicas pela questão das crianças: "A sociedade civil fala, mas na prática não tem ação. Nem para as escolhas desses Conselhos há uma mobilização; muito menos para a cobrança de um árduo trabalho" (entrevista, janeiro de 
2004). Outra promotora entrevistada compartilha dessa opinião e alerta para a invisibilidade política da questão: “O custo de não tratar do menor para os governantes é nulo; porque a sociedade não cobra; então o problema fica sem perspectiva de melhora" (entrevista, março de 2004).

A especificidade do lugar da criança e da adolescência na vida pública explica, portanto, o relativo isolamento do Ministério Público e do Judiciário, que, conforme se verificou na entrevista com seus representantes, parecem estar sozinhos no exercício do papel de porta-vozes desse segmento, sobretudo quando se considera a atribuição de pressionar o poder público em nome dos direitos universais das crianças e adolescentes. A título de informação, registre-se que, entre 1996 e 2003, o Ministério Público ajuizou 77 Ações Civis Públicas na Vara de Infância e Juventude contra a prefeitura do Rio de Janeiro e apenas três não foram acolhidas pelo Judiciário.

\section{II.2 - A Sustentação Jurídica do Pleito}

Conforme já assinalado, a construção jurídica desse pleito baseia-se no art. 227 da Constituição Federal e em vários artigos do ECA. É importante acrescentar que, em suas alegações, o Ministério Público observa que a Constituição adotou a doutrina da "proteção integral da criança e do adolescente, ao assegurar-lhes todos os direitos fundamentais necessários para proporcionar-lhes o desenvolvimento pleno como seres humanos". Em suas razões, mobiliza também a Lei no 10.216/01, que em seu art. 2º, § único, incisos I e III, estabelece "que são direitos da pessoa portadora de transtorno mental ter acesso ao melhor tratamento do sistema de saúde, consentâneo às suas necessidades e ser protegida contra qualquer forma de abuso e exploração" (Processo II, 9 e ss.).

Outro aspecto importante, que nem precisou ser muito enfatizado na sustentação jurídica do pleito, refere-se à legitimidade do pólo passivo, já que o princípio da descentralização político-administrativa presente na Constituição, bem como a postulação do ECA (art. 88, I, III) pela descentralização da política de atendimento a crianças e adolescentes, favorecem a identificação do município como responsável pelo serviço reclamado.

O pedido de antecipação de tutela é justificado pelo Ministério Público como uma forma de atenuar os efeitos que terá sobre as crianças o fato de que "possivelmente esta ação será objeto de incontáveis recursos 
por parte do réu". E é também solicitado ao juiz que o município "disponibilize, no prazo de 30 dias, um mínimo de 10 leitos em unidade hospitalar do Município (cinco para meninos e cinco para meninas), em setor separado do destinado a pacientes psiquiátricos, para internação de crianças e adolescentes dependentes de drogas e substâncias afins que necessitem de desintoxicação e / ou tratamento em regime de internação". Demanda, ainda, que "caso a determinação anterior não seja atendida, que o réu seja obrigado a arcar com os custos das internações de crianças e adolescentes [...]"; e que "ofereça, em pelo menos uma unidade de saúde de cada uma das AP's da Cidade, atendimento em regime ambulatorial para crianças e dependentes [...], dotando os citados serviços de equipamento e de pessoal especializado, sob pena de multa diária" (Processo II, 15 e ss.). Por fim, e de modo mais amplo, para avaliação do mérito da ação, o Ministério Público solicita "a citação do réu, na pessoa de seu representante legal, ampliando seu pedido anterior de 10 leitos para um mínimo de 16 leitos e reiterando o pleito do estabelecimento de multa para o caso de descumprimento das determinações anteriores" (idem).

Verifica-se, assim, que o pedido do Ministério Público, ao contrário do que se observou no caso dos medicamentos, já contém uma proposição de política pública definida e formatada pelos promotores, sem que, aparentemente, estes tenham efetuado maiores consultas a especialistas. Embora não tenha sido possível aprofundar essa questão, a pesquisa consultou uma das maiores especialistas em drogadição do Rio de Janeiro, professora e pesquisadora da Universidade do Estado do Rio de Janeiro - UERJ, que milita há mais de duas décadas nessa área da saúde. Ela disse desconhecer a ação movida pelo Ministério Público, mas, quando informada de seu conteúdo, mostrou-se cética quanto aos seus resultados, pois, para ela, tais decisões são como "fogos de artifício", que chamam a atenção da mídia, mas não são sustentáveis, contribuindo, inclusive, para retirar a credibilidade dos próprios médicos, já que, segundo afirma, o tratamento de viciados em drogas é muito complexo, sobretudo de crianças. Disse ainda que, "se tivesse que apostar todas as fichas apostaria na prevenção, pois o problema tem de ser tratado como uma epidemia, o que supõe uma abordagem intensiva e cotidiana" (entrevista, março de 2004).

Evidentemente que, ao trazer a opinião da citada pesquisadora, não se pretende colocar em debate a consistência da ação, mas tão somente sublinhar o isolamento que parece caracterizar a atuação do Ministério 
Público, e a própria decisão judicial, na proposição de ações que visam a defesa de interesses coletivos das crianças e dos adolescentes.

\section{II.3 - A Construção da Decisão Judicial}

O pedido de liminar do Ministério Público foi acolhido pelo Juiz da $1^{\text {a }}$ Vara de Infância e Juventude, suscitando recurso da prefeitura, que alegou, entre outras justificativas, a "impossibilidade de atendimento ao pedido no prazo determinado na decisão liminar", invocando, para tanto, "dificuldades de ordem orçamentárias". Além disso, alegou haver "indevida interferência na discricionariedade inerente ao Poder Executivo municipal", sustentando que "as normas previstas nos artigos 203 e 208 da C.F. são de caráter programático, de aplicação diferida e não imediata, não se admitindo que o Judiciário ou o Ministério Público interfiram nesta questão" (Processo II, 20).

Verifica-se, aqui, a recorrente discussão sobre a auto-aplicabilidade de normas constitucionais que, no entendimento do poder público, seriam de natureza programática. Na verdade, esse debate, embora travado no interior do rito jurídico, é eminentemente político, estando em jogo, de um lado, a postulação de autonomia administrativa por parte do poder constituído pelo voto, no caso, o Executivo, e, de outro, a postulação do poder constituído por delegação constitucional, no caso, o Ministério Público, que reivindica a auto-aplicabilidade da norma constitucional.

Para conferir maior sustentabilidade à sua concepção, o Ministério Público alega, em sua réplica, que o princípio da "prioridade absoluta" conferido aos direitos da criança "teve como objetivo espancar qualquer dúvida quanto à aplicabilidade do preceito constitucional", no que foi "reiterada pelo ECA", conforme se observa em seu artigo $4 \stackrel{\circ}{\circ}$, em especial na alínea d, parágrafo único, que estabelece que a garantia da prioridade compreende "destinação privilegiada de recursos públicos nas áreas relacionadas com a proteção à infância e à juventude" (Processo II, 224 e ss.).

Tal tese é sustentada doutrinariamente, recorrendo-se a Wilson Liberati - Promotor de Justiça da Infância - que, em livro sobre o ECA, defende que "na área administrativa, enquanto não existirem creches, escolas, postos de saúde [...] não se deveria asfaltar ruas, construir sambódromos [...]"; e jurisprudencialmente, a partir da citação do acórdão do Tribunal de Justiça do Distrito Federal, que estabelece que "do estudo 
atento desses dispositivos legais e constitucionais, dessume-se que não é facultado à administração alegar falta de recursos orçamentários para a construção dos estabelecimentos aludidos, uma vez que a Lei Maior exige PRIORIDADE ABSOLUTA (art. 227) e determina a inclusão de recursos no orçamento. Se, de fato, não há, é porque houve desobediência, consciente ou não, pouco importa [...]" (idem, ênfase do acórdão).

É também através da mobilização de doutrina e jurisprudência que o Ministério Público ataca o argumento da invasão de competência sustentado pela prefeitura. E, com essa orientação, acentua o papel do Judiciário, invocando o trabalho de doutrina publicado em 1993, no Rio Grande do Sul, por Jussá Jessé de Bragança Soares, intitulado “Instrumentos Processuais no ECA", o qual sustenta que, "se faltarem vontade política e eficiência prática dos demais poderes, resta ao Judiciário ocupar o espaço aberto, conquistando-o até fixar seus próprios limites. Se não o fizer, quando diante do caso concreto, estará tomando uma postura conservadora, timorata, ante as doutrinas consolidadas, cúmplice da história de iniqüidade que infelicita nosso povo" (ibidem).

Paralelamente a isso, o Ministério Público defende seu papel de representante funcional da sociedade, garantindo-lhe a consecução de direitos já adquiridos. Para tanto, convoca a sentença do Tribunal de Justiça do Estado de São Paulo, que afirma que

“[...] não se pode negar ao Ministério Público a legitimidade na defesa do cumprimento das normas constitucionais, sob o argumento da independência entre os poderes, enquanto praticam atos administrativos 'interna corporis'. Não são independentes para, a seu talante, desobedecerem à carta política, às leis e, sob tal pálio, permanecerem, cada um a seu lado, imunes à reparação das ilegalidades" (ibidem).

Assim é que o Ministério Público se socorre de uma tese ativista, buscando por essa via dar sustentação e legitimidade jurídica à sua atuação enquanto instituição que, em nome da defesa dos direitos constitucionais, procura intervir na agenda administrativa constituída pelos poderes políticos.

Durante o ano de 2002, após o acolhimento do pedido de liminar por parte da Vara de Infância e Juventude, o Ministério Público tomou medidas no sentido de obrigar o poder municipal a cumprir a determinação judicial. Tal pressão não deixou indiferente o poder público muni- 
cipal. Prova disso é que, em agosto de 2002, a Secretaria Municipal de Saúde afirma estar ultimando as obras para a implantação do Centro de Apoio Psicoterápico Raul Seixas, e que, em setembro, teria início "o treinamento de profissionais que irão compor a equipe do serviço"; e, finalmente, que trabalhava para "qualificar os quadros da rede, de forma a garantir a oferta de, pelo menos, uma referência de tratamento em cada área de planejamento da cidade" (Processo II, 324).

Em novembro de 2002, quase um ano após o deferimento do pedido de liminar, em audiência realizada na I Vara de Infância e Juventude, os representantes da prefeitura chegaram a propor aos promotores do Ministério Público a celebração de um Termo de Ajustamento de Conduta, que, no entanto, acabaria não sendo assinado (idem, 224 e ss.). Finalmente, em janeiro de 2003, a prefeitura entrou com Agravo de Instrumento junto à $13^{a}$ Câmara Cível, contra a decisão do juiz da $1^{\text {a }}$ Vara de Infância de Juventude, que em sua sentença fixara multa diária no valor de cinco salários-mínimos pelo descumprimento de liminar que deferiu o pleito. $\mathrm{O}$ recurso foi recusado.

Portanto, ao contrário do que se verifica no caso dos medicamentos, a decisão judicial da ação dos drogaditos não foi construída a partir de um processo de negociação. Como evidencia a análise do processo e confirmam as entrevistas concedidas pelas partes envolvidas, a lógica dessa ação pautou-se pela seguinte dinâmica: dado que tanto o Ministério Público quanto o Judiciário se mostravam descrentes da possibilidade de negociação, em razão do reiterado descumprimento de promessas por parte da administração pública, não consideraram outra alternativa senão o exercício de permanente pressão sobre ela, valendo-se, para tanto, de mecanismos como a cobrança de multa, telefonemas às autoridades - recurso bastante comum segundo o juiz do casoe utilização da mídia como forma de mobilizar a opinião pública. Contudo, da parte do poder público, a tônica da ação foi a resistência e, como afirmou o responsável pela área de saúde mental da prefeitura:

“A Ação Civil Pública em questão é inexeqüível, tanto pelo prazo de efetivação quanto pela magnitude dos recursos. A demanda dos 16 leitos é absurda, o número é exorbitante, porque já não há espaço para doentes em estado terminal em vários hospitais. O programa de atendimento ambulatorial, com profissionais treinados e todos os seus dispositivos, requer uma mobilização muito grande de recursos" (entrevista, agosto de 2004). 


\section{II.4 - A Efetividade da Ação}

Em fevereiro de 2004, com a negação do recurso da prefeitura pelo Tribunal, a sentença do juiz de $1^{\text {a }}$ instância foi confirmada, tornando mais delicada a resistência apresentada pelo poder público em cumprir a ordem judicial. Por isso mesmo, a prefeitura baixou, através da Secretaria Municipal de Saúde, uma resolução (nº 1.046/04) "instituindo, no âmbito do Sistema Único de Saúde na Cidade do Rio de Janeiro, o fluxo de encaminhamento de jovens com problemas decorrentes do uso abusivo de álcool e outras drogas". O documento comprova o funcionamento de 10 locais de referência para tratamento ambulatorial de menor complexidade, ou seja, para as situações que não apresentam denominado "risco psicossocial". Esses centros estão distribuídos nas cinco APs do município ${ }^{17}$. Ainda segundo a referida resolução, a prefeitura compromete-se a oferecer atendimento médico e psicológico, além de "atuar de forma a estimular o convívio com os familiares ou família acolhedora ou acompanhar os jovens que estejam sendo atendidos por abrigos, albergues ou suporte moradia".

Após tomar conhecimento dessa resolução, a pesquisa voltou a procurar a promotora responsável pelo caso, que demonstrou satisfação, afirmando que já estava se preparando para fiscalizar "se ela (a resolução) está sendo cumprida". Afirmou também estar ultimando o cálculo da multa que, segundo ela, teria que ser paga pela prefeitura, retroativa a 2002, por descumprir decisão judicial durante quase dois anos. Quando questionada se acreditava que a Prefeitura, de fato, saldaria aquela dívida respondeu: "terá que pagar, se não o responsável será processado e preso" (entrevista, agosto de 2004).

Portanto, do ponto de vista da efetividade, a exemplo do que já se verificara no caso dos medicamentos, não resta dúvida de que, ainda que parcialmente, a ação surtiu efeitos concretos, forçando a implantação de uma política pública até então inexistente na administração municipal. Entretanto, na opinião de uma das promotoras entrevistadas, seus efeitos são ainda mais abrangentes, na medida em que "cumprem um papel pedagógico, como tijolinhos de uma construção". São "um poderoso instrumento de transformação", afirma outro promotor entrevistado (entrevistas realizadas em janeiro e fevereiro de 2004).A esse respeito, não deixa de ser interessante a postura assumida pela autoridade municipal a quem cabe a responsabilidade pela matéria, e que já se mostrara crítica veemente da ação dos drogaditos, quando admite que 
a ação tem o mérito de fortalecer a Secretaria de Saúde Mental: "assim a gente vira interlocutor", evidenciando que a ação judicial acabou provocando uma redefinição da escala de prioridades no âmbito da agenda do poder municipal.

Assim, a batalha "quixotesca" do Ministério Público e do Judiciário em torno da questão da drogadição de crianças e adolescentes parece ter alcançado êxito, incorporando à agenda pública um tema que não lhe teria chegado pela via da política. A ausência da sociedade civil organizada ao longo de todo o embate, no entanto, cobrará seu preço, pois somente uma fiscalização continuada da qualidade dos serviços e um envolvimento mais amplo das instituições de ensino e de pesquisa na matéria poderão assegurar uma efetiva resposta ao problema. Enquanto a questão permanecer invisível para a sociedade, dificilmente o poder público terá motivos para conferir prioridade à matéria. $\mathrm{E}$, sozinhos, $\mathrm{o}$ Ministério Público e o Judiciário não terão como sustentar tal agenda por muito tempo.

\section{0 CASO DA ILHA GRANDE}

Trata-se do Termo de Ajustamento de Conduta envolvendo a Ilha Grande, situada em Angra dos Reis, no litoral sul do Estado do Rio de Janeiro. O acordo, levado a efeito pelos Ministérios Públicos Estadual e Federal, foi assinado em 20 janeiro de 2002, pela Prefeitura Municipal de Angra dos Reis, Secretaria Estadual de Meio Ambiente e Desenvolvimento Sustentável, Fundação Estadual de Engenharia do Meio Ambiente - FEEMA, Instituto Estadual de Florestas - IEF, Universidade do Estado do Rio de Janeiro, Instituto Brasileiro de Meio Ambiente, e pelo Ministério do Meio Ambiente.

Ilha Grande é uma área considerada de grande valor ambiental e vem sendo alvo de iniciativas legais para a criação de unidades de conservação, subordinadas aos órgãos estaduais voltados para o meio ambiente. Tal é o caso do Parque Estadual da Ilha Grande, de competência do Instituto Estadual de Florestas, e os casos da Reserva Biológica da Praia do Sul, do Parque Estadual Marinho do Aventureiro e da Área de Proteção Ambiental Tamoios, todos de competência da Fundação Estadual de Engenharia do Meio Ambiente. Ademais, por ser uma Ilha, a União também tem competência sobre a área ${ }^{18}$. Entretanto, do ponto de vista da jurisdição político-administrativa, o órgão responsável pela Ilha é a Prefeitura Municipal de Angra dos Reis, interlocutora direta da 
população que ali reside. Compreende-se, assim, a presença de tantos signatários no Termo de Ajustamento de Conduta.

Em linhas gerais, o objetivo do acordo é o de estabelecer uma gestão compartilhada da Ilha Grande, atacando os principais problemas identificados, como a questão do saneamento, do lixo, do turismo predatório e do uso irregular do solo.

É importante frisar que o Termo de Ajustamento de Conduta é um procedimento pré-processual utilizado pelo Ministério Público, que gera um título executivo extrajudicial. A promoção do Termo de Ajustamento de Conduta é uma das prerrogativas constitucionais do Ministério Público e tem sido amplamente utilizada como forma de se evitar a judicialização do conflito. Trata-se, portanto, de uma das vias privilegiadas de afirmação de novos direitos coletivos, na medida em que submete um conflito coletivo à arbitragem, mediada pelo Ministério Público, a fim de estabelecer um acordo, formalizado no Termo de Ajustamento de Conduta, em que tais direitos passam a ser regulados. Tal acordo, caso descumprido, pode vir a se traduzir em um processo judicial. Daí a importância de incluí-lo no conjunto de casos estudados.

A seleção do Termo de Ajustamento de Conduta da Ilha Grande como objeto de pesquisa deveu-se à percepção de que ele continha alguns elementos importantes para os objetivos deste trabalho, tanto por sua complexidade, já que envolve diversos segmentos do poder público, quanto por seu alcance, uma vez que funciona como uma espécie de plano diretor de uma ilha onde vivem pouco mais de 1.000 moradores, mas que é freqüentada nas estações de férias por mais de 50 mil turistas.

\section{III.1 - Antecedentes}

Segundo foi possível apurar através de entrevistas realizadas com os diferentes segmentos envolvidos na elaboração do Termo de Ajustamento de Conduta, inclusive as organizações da sociedade civil local, sua origem está relacionada com a crise urbana e ambiental deflagrada pela ampliação do turismo na Ilha e pelo aumento da especulação imobiliária. A implosão do presídio existente na Ilha, em 1994, teria favorecido ambos os processos.

É válido apresentar alguns trechos de depoimentos colhidos pela pesquisa, dando conta dessa crise urbana e ambiental: 
"Historicamente, a ilha passou por todos os ciclos econômicos do desenvolvimento do Brasil, e por conta disso já foi, por diversas vezes, desmatada e desabitada também. Foi também local de cárcere; a Marinha construiu um presídio e, por conta disso, desenvolveu-se ali uma cultura carcerária que se misturou à cultura caiçara. Angra dos Reis foi um dos últimos lugares a se desenvolver, mas, com a chegada de grandes empreendimentos, como estradas de ferro, a construção da usina de Angra III, além da especulação imobiliária, houve um crescimento populacional, e esse processo foi agravado, mais tarde, pela implosão do presídio de Ilha Grande" (entrevista concedida pelo dirigente do Comitê de Defesa da Ilha Grande - Codig, outubro de 2003).

"Ao longo do tempo, Angra dos Reis foi sendo invadida e ao mesmo tempo privatizada, e a Ilha Grande não ficou fora desse processo. Os grandes empreendimentos de Angra expulsaram os caiçaras dos seus lugares de origem, onde viviam da pesca, por exemplo, e esse foi um dos motivos que deu impulso ao processo de favelização de Angra e da Ilha Grande, mais especificamente" (entrevista concedida pelo dirigente da Sociedade Angrense de Proteção Ecológica - SAPÊ, março de 2004).

"Com o crescimento desordenado da Ilha Grande [...], a Vila do Abraão, porta de entrada da Ilha, vem ganhando cada vez mais um perfil cosmopolita, que representa tudo aquilo em que a comunidade local não quer se transformar. Saneamento básico super precário, problema de drogas, prostituição e favelização são alguns dos problemas mais graves que vêm se constatando" (entrevista concedida por pesquisadora do Centro de Estudos Ambientais e Desenvolvimento Sustentável da UERJ/Ilha Grande, janeiro de 2004).

Esses depoimentos evidenciam que a percepção de crise urbana e ambiental da Ilha Grande está bastante difundida, tendo deflagrado, sobretudo a partir de 2000, um processo de mobilização mais organizado: "No Carnaval de 2000, um grupo de amigos, assustado com a superlotação da Ilha, resolveu fazer um abaixo-assinado para chamar a atenção da prefeitura para os problemas ambientais que a Ilha vinha sofrendo" (entrevista concedida por membro do CODIG, outubro de 2003).

Ao que tudo indica, no entanto, a pressão sobre a prefeitura não se mostraria eficiente e não traria resultados concretos. Como apontou uma liderança do movimento ambientalista local: "A relação com a prefeitura é muito complicada. É uma questão histórica de corrupção. [...] Com a sanção judicial, o bem público vem se tornando privado. [...] 
Em Angra tudo é proibido e tudo pode, e tem a benção do poder público" (entrevista, março de 2004).

Por seu turno, um dos quadros da Prefeitura de Angra dos Reis entrevistado pela pesquisa acusa a baixa representatividade dos grupos ambientalistas locais: "O CODIG se resume a dois e o SAPÊ também se resume a poucos, e elas se vêem com o dever de, através do movimento ambiental, defender a ilha, por isso se mantêm" (entrevista, setembro de 2004).

Configura-se, assim, uma dinâmica que certamente não é exclusividade de Angra dos Reis. De um lado, a sociedade civil organizada em ONGs e associações, com baixa penetração popular e, de outro, um poder público que, ancorado na lógica do voto, resiste em reconhecer a legitimidade desses grupos. É nesse contexto que o Ministério Público passa a ser um interlocutor privilegiado dos grupos organizados da sociedade civil, como ocorreu no caso da Ilha Grande. Mais do que isso, a mobilização do Ministério Público passa a ser fator estruturante da própria organização social, como evidente no trecho encontrado na página eletrônica do CODIG, transcrito a seguir:

“No período do Carnaval de 2000, um grupo de pessoas que vive na Ilha Grande se reuniu e elaborou um documento denominado Manifesto em Defesa da Ilha Grande, no qual se recolheu 5500 (cinco mil e quinhentas) assinaturas entre moradores da Ilha e turistas de várias partes do mundo. Esse documento denunciava a falta de interesse do poder público em relação às questões ambientais na Ilha Grande. Através dele, acionamos o Ministério Público, como fiscal da lei, no sentido de adotar medidas para privilegiar os interesses sociais e coletivos relacionados com os moradores e com o meio ambiente. Logo percebemos que esse grupo teria que atuar mais decisivamente nas questões ambientais da Ilha Grande, pois estavam acontecendo inúmeros desrespeitos em relação à Legislação Ambiental. Isso nos fez buscar novas formas de organização. Criou-se, então, o Comitê de Defesa da Ilha Grande" (www.codig.org.br, ênfases nossas).

O recurso ao Ministério Público, portanto, passa a ser encarado como via de tradução do sentimento de crise urbana e ambiental em uma ação política e administrativa. Até porque, a pressão sobre o poder público local implicaria uma mobilização mais ampla, necessariamente custosa e difícil. Indagado sobre a via judicial, uma liderança do movimento ambientalista local admitiu: “É a única alternativa de que dispomos" (entrevista, março de 2004). 
Uma simples visita à Promotoria local é bastante para que se verifique a importância dessa interlocução para a vida de Angra dos Reis. No painel afixado na entrada da Promotoria, encontram-se publicadas diversas ações coletivas e inquéritos na área do meio ambiente, a grande maioria animada pelas associações e ONGs ambientalistas locais. $\mathrm{O}$ membro da Prefeitura de Angra dos Reis entrevistado vai no ponto: "O CODIG e o SAPÊ denunciam, e o MP se encarrega de abrir um inquérito administrativo" (entrevista, setembro de 2004).

No caso específico do Termo de Ajustamento de Conduta da Ilha Grande, a versão da Prefeitura de Angra dos Reis sobre a motivação original da iniciativa é diferente da apresentada pelas lideranças ambientalistas. De acordo com o representante entrevistado da prefeitura, esse Termo foi provocado pelo Ministério do Meio Ambiente, que teria mobilizado o Ministério Público Federal: "O Ministro José Sarney Filho convocou o IBAMA e o MPF, pois queria terminar seu mandato com algum grande feito e, assim, pediu a assinatura de um Termo de Ajustamento de Conduta, que não teve nenhum estudo prévio" (idem).

É provável que as duas versões sejam complementares, pois possivelmente o ministro tomara ciência do caso da Ilha Grande através da provocação dos Ministérios Públicos Estadual e Federal pelos ambientalistas. O mais importante, contudo, é que a versão apresentada pela prefeitura leva a crer que o Termo de Ajustamento de Conduta foi percebido como uma forma de intervenção federal sobre a administração municipal, com a sobreposição da vontade da União sobre a local. Não surpreende, por isso mesmo, a nítida falta de entusiasmo da prefeitura com o cumprimento dos seus termos.

No dia 20 de janeiro de 2002, dia de São Sebastião, padroeiro da Vila de Abraão, o termo é assinado, em solenidade realizada no Casarão da Cultura, localizado no Abraão, que contou com a presença do ministro do Meio Ambiente, do secretário de Estado do Meio Ambiente, do prefeito de Angra dos Reis e de outras autoridades. O evento teve ampla cobertura da imprensa. No dia seguinte, no Jornal do Brasil, por exemplo, o evento ocupou uma página inteira, merecendo a seguinte manchete: "Acordo Protege Ilha Grande". No corpo da matéria, o leitor é informado de que o Termo de Ajustamento de Conduta foi resultado de um consenso entre os três níveis do poder público, e que o projeto iria receber $\mathrm{R} \$ 1,5$ milhão do Ministério do Meio Ambiente, e mais $\mathrm{R} \$$ 112 mil do governo do Estado (Jornal do Brasil, 21/1/2002). 
De acordo com relato de uma pesquisadora da UERJ, cerca de 100 pessoas teriam presenciado a solenidade, muito poucas, contudo, habitantes da Ilha, já que essas estavam maciçamente envolvidas com os eventos relacionados a São Sebastião. "A maioria era composta por donos de pousadas e de estabelecimentos comerciais locais, além de pessoas ligadas às entidades diretamente envolvidas com o TAC". Segundo a pesquisadora, a ausência dos habitantes da Ilha teria, inclusive, gerado "um certo mal-estar", pois as autoridades em seus discursos faziam recorrentes referências aos caiçaras - tidos como verdadeiros nativos da Ilha - apresentados como o público-alvo prioritário do Termo de Ajustamento de Conduta.

A circunstância daquela solenidade não deixa de evidenciar que, apesar da participação dos ambientalistas, o Termo de Ajustamento de Conduta não contou com uma participação mais ampla da sociedade local. Aliás, as próprias lideranças das organizações ambientalistas regionais sentiram-se excluídas do processo: "A sociedade civil não está presente no TAC, nem diretamente representada nele" (entrevista concedida por membro do CODIG). "Não foi levada em consideração a vontade da comunidade. Foi um acordo de cima para baixo" (entrevista concedida por membro da SAPÊ).

Nesse ponto, os ambientalistas e a prefeitura parecem estar de acordo, pois, segundo o representante do poder público local: "A Procuradora Geral do Rio de Janeiro, junto com a promotora do Ministério Público Estadual escreveram o TAC, em agosto de 2001. Elas convocaram as partes signatárias do TAC para algumas reuniões, mas não para estipular um acordo, pois o TAC já estava formatado" (entrevista concedida por membro da prefeitura).

Assim, se de um lado o Termo de Ajustamento de Conduta foi concebido a partir de uma abordagem técnica e jurídica, características que ajudam a compreender sua lenta e difícil execução, e em especial a postura da prefeitura, que não demonstra maior interesse em levar adiante os pontos acordados, de outro lado, e como contraponto à postura do poder público local, o Termo de Ajustamento de Conduta vai sendo progressivamente incorporado como instrumento de luta por parte dos ambientalistas, que procuram estreitar sua relação com o Ministério Público, tanto no âmbito estadual, quanto no federal. 


\section{III.2 - A Estrutura do Termo de Ajustamento de Conduta}

A definição do escopo do Termo de Ajustamento de Conduta é antecedida pela menção ao artigo 225 da Constituição Federal, caput, que trata do direito ao Meio Ambiente, ao artigo 3ㅜㅡ, inciso I, da Lei no ${ }^{-6.938 / 81}$ (conhecida como Lei do Meio Ambiente), e por um conjunto de premissas, do qual cabe destacar "o interesse comum das partes em preservar o patrimônio natural da Ilha Grande, resguardando seu desenvolvimento econômico, em acordo com a melhoria de qualidade de vida da população e o atendimento às exigências das políticas ambientais vigentes" (Termo de Ajustamento de Conduta, p. 2).

Outra premissa a ser sublinhada é a que faz referência às operações já realizadas através do Plano Básico de Ordenação Ambiental da Ilha Grande, cujo objetivo teria sido o de "reduzir de imediato o efeito predatório dos atuais usos e da exploração desordenada da Ilha" (ibidem). Ainda em suas considerações iniciais, o documento destaca os problemas do saneamento e do lixo, como itens privilegiados da intervenção proposta pelo Termo de Ajustamento de Conduta.

Em sua primeira cláusula, o Termo de Ajustamento de Conduta

“[...] estabelece os prazos e as condições para que as partes obrigadas promovam fiel e integralmente as ações mitigadoras [...] relativas aos seguintes problemas da Ilha Grande": saneamento das áreas com concentração populacional; coleta do lixo; questão dos escombros do antigo presídio; ordenação da ocupação dos imóveis do Estado sob a administração da UERJ e da Prefeitura Municipal de Angra dos Reis; elaboração de plano de gestão ambiental; e recuperação da área degradada pelos depósitos irregulares de lixo (idem:3).

Quanto à distribuição de responsabilidades, o TAC estabelece que cabe à Prefeitura de Angra dos Reis a realização das tarefas mais importantes para a consecução dos objetivos pretendidos tanto em seu planejamento, quanto em sua execução. O Termo de Ajustamento de Conduta "obriga o Município de Angra dos Reis a apresentar, em 120 dias, Plano de Implantação dos Sistemas de Saneamento" em diferentes localidades da Ilha Grande; plano de gestão do lixo; e de recuperação das áreas degradadas. Estabelece, ainda, critérios para o desenvolvimento do plano, como o que determina que a "população que vive no e do lixo participe no planejamento da gestão do lixo urbano". 
Fica evidente, portanto, que o Termo impõe ao Executivo local um conjunto de exigências, subordinando o poder constituído pelo voto a instrumentos e instituições da representação funcional. Por isso, para que se compreenda a concordância da prefeitura com tais imposições, é necessário considerar o compromisso assumido pelo Ministério do Meio Ambiente de "financiar as solicitações de Angra, com referência à implantação do Plano de Gestão de Resíduos Sólidos, e a execução do Projeto de Recuperação de Áreas Degradadas, no limite máximo de R\$ 1.500.000,00". Bem como, de "disponibilizar, para o Município de Angra dos Reis, uma barcaça [...] para o transporte dos resíduos sólidos da Ilha Grande para o continente". Também deve ter pesado o fato de o governo do Estado do Rio de Janeiro, através da Secretaria Estadual do Meio Ambiente, comprometer-se a "aportar recursos do Programa Estadual de Controle de Lixo Urbano, no valor de R\$112.000,00 para o Plano de Gestão de Resíduos Sólidos".

Em sua cláusula terceira, o Termo de Ajustamento de Conduta atribui à FEEMA, IEF e ao Município o desenvolvimento de um plano piloto para a "ordenação do acesso e definição de capacidade de suporte a visitantes da Ilha; e consolidação de procedimentos e normas para a realização de obras e construções" (TAC:8). Mas, talvez, a maior evidência da natureza tecnocrática do Termo de Ajustamento de Conduta esteja em sua cláusula quarta, que determina a "imediata criação de um Comitê Técnico Operacional, para o encaminhamento das atribuições fixadas no TAC, o qual será composto por 2 representantes de cada uma das partes signatárias", cabendo à FEEMA a coordenação do referido Comitê. Reforçando essa característica, o seu anexo, que define as condições mínimas para o Plano de Gestão dos Resíduos Sólidos, estabelece, entre outras coisas, que o Município de Angra dos Reis se compromete a "instituir instrumentos legais, institucionais e financeiros específicos - leis, normas, diretrizes e políticas para a gestão de resíduos sólidos -, capazes de garantir a sustentabilidade ambiental e econômica dos sistemas implantados". Portanto, também o Poder Legislativo local fica submetido a uma vontade politicamente constituída pela via da representação funcional.

\section{III.3 - A Efetividade do Termo de Ajustamento de Conduta}

O documento intitulado "Subsídios para Análise do Desempenho da Prefeitura de Angra dos Reis", de maio de 2003, e assinado pela presidente do CoDIG, deixa evidente a baixa eficácia do Termo de Ajusta- 
mento de Conduta, como se verifica no contundente manifesto, que apresenta um melancólico balanço: "Gerencialmente mal conduzido, 16 meses após sua assinatura, o TAC caminha para o fracasso total. Indiferente aos insistentes apelos que os segmentos da sociedade, ambientalistas e moradores da Ilha Grande têm feito ao longo desse período, alguns agentes públicos tem-se mantido na mais absoluta indiferença e não oferecem nenhuma resposta" (TAC:1).

O manifesto concentra suas críticas na prefeitura, a quem acusa de indiferença diante dos prazos e exigências estabelecidos pelo Termo de Ajustamento de Conduta, e posiciona a sociedade civil organizada como aliada do acordo nele contido e, por conseguinte, do Ministério Público, que passa a ser, por isso mesmo, alvo principal de suas melhores expectativas, como se constata no seguinte trecho do manifesto: "Lamentamos que um resultado desfavorável dos trabalhos do TAC possa contribuir para o aumento da degradação ao meio ambiente da Ilha Grande, já tão agredida, e ainda desfechar um duro golpe na imagem das instituições signatárias, em especial na do Ministério Público, que como todos sabem, esforça-se para garantir a aplicação da lei em nosso país (TAC:1, ênfases dos autores).

Como já se observou, o Termo de Ajustamento de Conduta não contemplou, originalmente, a participação da sociedade civil organizada, situação que teria sido modificada após pressão exercida por ONGs e associações locais, e que teve seu ponto culminante em uma audiência pública, na qual a questão foi resolvida.

O futuro do Termo de Ajustamento de Conduta da Ilha Grande, portanto, está contido no seguinte conflito: de um lado, o Ministério Público Estadual e Federal e as entidades da sociedade civil e, de outro, a prefeitura e o Poder Legislativo. O caso da Ilha Grande enseja, portanto, uma forte evidência dessa nova arena de conflitos criada a partir da Carta de 1988, na qual o Ministério Público e entidades da sociedade civil se unem para pressionar os poderes políticos.

Contudo, sem que haja paradoxo, essa mesma dinâmica também poderá criar uma facilitação política para o poder público local vis-à-vis os grupos econômicos hegemônicos na região. Pois, como no caso estudado, se é verdade que o Termo de Ajustamento de Conduta funciona como um dispositivo político externo à lógica eleitoral local, por outro lado, ele cria a possibilidade de o poder municipal contrapor aos interesses econômicos que eventualmente o constrangem, os direitos cons- 
titucionais defendidos pelo Ministério Público e pela sociedade civil organizada. Com isso, abre-se a virtualidade de uma negociação que, ao que tudo indica, já tem sido percebida pelos promotores estaduais e procuradores federais envolvidos no conflito.

Ao ser entrevistada sobre a questão, a promotora que atua no Ministério Público de Angra dos Reis reconhece a dificuldade de obrigar o poder público, preferindo o caminho do diálogo: “O trabalho está sendo levado em torno do diálogo porque não há como obrigar a efetivação do Termo de Ajustamento de Conduta" (entrevista, março de 2004). Já o Procurador Federal de Angra dos Reis observa, com nitidez, o papel que o Ministério Público pode jogar, no sentido de minimizar o poder dos grandes interesses locais sobre a administração pública, contribuindo para tornar o governo local mais democrático: "A Procuradoria Geral da República tem que estar o tempo todo lidando com as prefeituras, pois a prefeitura, por sua vez, é extremamente pressionada pelos elos políticos, e a presença da Procuradoria no local intimida esse tipo de pressão" (entrevista, maio de 2004).

Caso se leve em conta apenas os efeitos tangíveis do Termo de Ajustamento de Conduta neste período de mais de dois anos de vigência, ou seja, sua capacidade de determinar um conjunto de ações concretas capazes de se traduzir em uma nova ordenação urbana da Ilha, o saldo será bastante modesto, quase insignificante. Não obstante, é preciso considerar que sua efetividade não se reduz aos efeitos mais imediatos, e o que a análise do caso sugere é que o Termo de Ajustamento de Conduta modificou os termos do conflito político, criando uma nova plataforma de luta para a sociedade civil organizada. De uma perspectiva democrática, essa arena envolvendo o Ministério Público e as ONGs locais não resolve a questão fundamental, já que dela não participa a grande maioria da população residente, mas sua simples existência impõe limites à submissão do poder político local e dos cidadãos aos grandes interesses, reequilibrando forças hoje muito desiguais.

\section{0 CASO DO LEASING}

Trata-se de Ação Civil Pública proposta em 1999 pela ANACONT, em face de 26 empresas financeiras de arrendamento mercantil (leasing), entre as quais empresas ligadas ao setor bancário como o UNIBANCO, o CITIBANK e o ITAÚ, e ao setor automobilístico, como a FIAT, a GM e a Mercedes Benz. 
Conforme consta da inicial do processo, "as rés firmaram com os consumidores contratos de arrendamento mercantil, visando aquisição de veículos automotores, estipulando prestações que deveriam observar a variação da moeda fixada em dólares americanos". No entanto, de acordo com a ANACONT, como houve alteração na política cambial do governo brasileiro, com a desvalorização da moeda nacional, "os consumidores foram levados ao desespero e tiveram suas prestações aumentadas em proporções astronômicas" (Processo no 99.001.016747-0, $427)^{19}$.

Por isso, a ANACONT postula que as rés se "abstenham de cobrar a variação cambial [...] passando a incidir o índice do INPC" (ibidem).

\section{IV.1 - Antecedentes}

$\mathrm{Na}$ área do consumidor, diferentemente do que vem ocorrendo na do meio ambiente ou na da criança, o Ministério Público não tem sido o principal responsável pelo ajuizamento de ações coletivas. Conforme pesquisa anteriormente realizada (Werneck Vianna e Burgos, 2002), naquela área tem-se destacado a atuação das associações de consumidores, respondendo por $70 \%$ de todas as ações coletivas ajuizadas no fórum do Rio de Janeiro, entre 1997 e 2001 . A mesma pesquisa indicou que os réus mais freqüentes das ações consumeristas são as empresas do setor financeiro (31,2\% do total) e as concessionárias privadas de serviços públicos (25\%).

Por esse motivo, considerou-se necessária a seleção de pelo menos um caso envolvendo esse importante ator do sistema de defesa dos direitos coletivos. Mas a escolha da ação do leasing também teve a seu favor o fato de ser um caso em que uma entidade da sociedade civil desafia praticamente todas as grandes empresas do sistema financeiro nacional, configurando, indiscutivelmente, um caso paradigmático para a jurisprudência e a doutrina sobre a matéria. Pois esta ação carrega todo o potencial contido neste instrumento processual, colocando o Judiciário no centro do sistema de defesa da sociedade contra os grandes interesses econômicos.

O Código de Defesa do Consumidor, sancionado em 1990, é o fundamento jurídico a partir do qual foi possível o desenvolvimento dessa espécie de conflito. Sua história remonta ao início dos anos 1980, quando são criados, em alguns estados, os Programas de Orientação e Proteção ao Consumidor-Procons ${ }^{20}$, voltados para a administração extraju- 
dicial de conflitos de consumidor. Na esteira das iniciativas voltadas para a modernização da regulação das relações de consumo, também foi criado, em 1984, o Juizado Especial de Pequenas Causas, que terá seu alcance ampliado, mais tarde, com a Constituição de 1988. Com a Lei da Ação Civil Pública, de 1985, cria-se a possibilidade de estabelecimento de ações coletivas na área do consumidor. Contudo, como bem salienta Filomeno (2001:386), antes do advento do Código de Defesa do Consumidor as ações de consumidor limitavam-se à tutela dos interesses difusos.

Em seu artigo 129, inciso III, que trata das atribuições do Ministério Público, a Constituição Federal de 1988 amplia o significado da ação coletiva previsto pela Lei da Ação Civil Pública, estabelecendo a figura do direito coletivo, que se diferencia do difuso, já que, diversamente deste, se refere a uma coleção de indivíduos definida, admitindo a divisibilidade. E o Código de Defesa do Consumidor (Lei nº 8.078 /1990), em seu artigo 81, adiciona uma nova classe de interesses coletivos, criando a categoria dos chamados interesses ou direitos individuais homogêneos. Ou seja, "na verdade cuida-se aqui da tutela de interesses individuais, mas tratados num enfeixamento que permite seu tratamento de forma coletiva, sobretudo no que tange aos efeitos da coisa julgada, que se iguala, em extensão subjetiva, aos interesses difusos [...] facilitando sobremaneira, conclui Filomeno, o acesso à justiça da massa de consumidores" (Filomeno, 2001:390-391). Com isso, contratos de adesão individuais, como os planos de saúde, por exemplo, são incluídos no rol das ações coletivas, ampliando a capacidade de defesa do consumidor individual diante das empresas.

O Código de Defesa do Consumidor representa, em suma, definitiva incorporação dos conflitos de consumidor na arena dos direitos coletivos. Quanto a isso, um dos aspectos a ser destacado refere-se à facilitação do acesso da sociedade civil organizada ao sistema de defesa de direitos coletivos, o que consolidava tendência verificada desde o debate em torno da Lei da Ação Civil Pública, que já trazia como uma de suas justificativas a necessidade de ampliação da legitimidade para postular ações coletivas ${ }^{21}$.

Com isso, em pouco tempo ganha novo impulso o processo de organização de entidades associativas especializadas na defesa do consumidor, que são fundadas sob um duplo registro: de um lado, como entidades capazes de atuar em conflitos individuais - o que as aproximam de 
escritórios de advocacia -e, de outro, enquanto agências vocacionadas para a defesa de interesses coletivos, no que se aproximariam das "sociedades de advogados de interesse público" norte-americanas.

O que o caso particular da ANACONT, autora da ação do leasing, parece indicar, é que essa ambigüidade é parte fundamental da sua própria estratégia de sobrevivência, já que o campo das ações coletivas ainda não assegura auto-sustentabilidade financeira. Conforme caracterização feita por um dos coordenadores da ANACONT, a entidade: "foi fundada em 1994, e não é uma empresa, não é um sindicato, e não tem interesse político. Não ganha nada do governo e nem mantém qualquer afiliação com parlamentares. É uma associação sem fins lucrativos, mas também não é filantrópica" (entrevista, julho de 2004). O mesmo entrevistado lembrou também que, embora ninguém receba salário fixo, "há remuneração pelo trabalho, apesar de boa parte dele ser realizado por estagiários, estudantes de direito ou bacharéis recém-formados" (idem).

A rentabilidade da associação depende fundamentalmente dos processos individuais e está organizada segundo "contratos de risco", tanto entre os advogados e a associação, que fica com uma parte do eventual ganho obtido nas lides, como entre a associação e o cliente, que em geral paga uma taxa de entrada, no valor de $\mathrm{R} \$ 50,00$, e mais $\mathrm{R} \$ 200,00$ pelo processo. Na hipótese de êxito, a associação fica com algo em torno de $20 \%$ do valor da indenização ou ressarcimento. Quanto às ações coletivas, segundo o dirigente da ANACONT, elas ainda não têm trazido retorno financeiro: "A ação coletiva pode gerar receita, mas, até hoje, somente duas deram retorno" (idem). Opinião semelhante foi apresentada pelo presidente da Associação de Defesa dos Consumidores ADCON, que também atua desde 1994 na defesa dos interesses coletivos, e que, desde então, já ingressou com 60 ações civis públicas, algumas delas vitoriosas, mas nenhuma integralmente efetivada (entrevista, março de 2004). De acordo com o dirigente da ANACONT, o problema estaria, em parte, na desconfiança com que o Judiciário encara as associações, situação que, no entanto, segundo ele próprio, começa a mudar: "Os membros do Judiciário geralmente não gostam das associações porque muitas realmente não são inteiramente éticas no seu trabalho [...]. Ao contrário de muitas associações, a Anacont já atua há dez anos e por isso tem mais confiabilidade. O Judiciário não tem nada contra a Anacont, pois averigua que ela é uma associação confiável" (entrevista, julho de 2004). 
De outra parte, contudo, existem dificuldades operacionais, que, segundo o dirigente da associação, ainda estão relacionadas à novidade do instituto jurídico: "Ninguém sabe ainda como executar a ação coletiva" (idem). Levando-se em conta tais dificuldades, que decerto não são sentidas apenas pelas duas entidades visitadas pela pesquisa, não espanta que o uso do espaço de representação coletiva pelas associações civis esteja ligado, de um modo ou de outro, não tanto à lógica empresarial, mas a uma concepção cívica do direito: "A Ação Civil Pública não é uma prioridade para a Anacont, mas quando surge a oportunidade, ela sente que tem a obrigação de entrar. Pois além do consumidor, ela defende o cidadão" (idem). Na mesma linha, o presidente da ADCON aposta na ação coletiva "como um poderoso instrumento de controle da sociedade contra os pequenos e grandes abusos cometidos pelas empresas" (entrevista, março de 2004).

Apesar disso, nada impede que venhamos a experimentar o mesmo dilema que vem sendo enfrentado nos EUA, em decorrência da transformação das class actions em um rentável negócio para entidades civis supostamente sem fins lucrativos, bem como para advogados especializados em flagrar pequenos danos cometidos pelas empresas. Em face disso, os críticos do modelo atual questionam a perversão do espírito público do instrumento, enquanto seus defensores salientam que ele produz um salutar regulatory enforcement ao constranger pequenos abusos cometidos pelas empresas, dificilmente passíveis de fiscalização por parte do poder público (Hensler et alii, 2000:69 e ss.).

\section{IV.2 - A Sustentação Jurídica do Pleito e a Construção da Decisão}

A tônica sustentada pela ANACONT é a de que o contrato de arrendamento estabelecido entre os consumidores e as empresas é desigual em seus efeitos, "ficando claro que a perda só tende ao consumidor e nunca ao credor arrendante" (Processo III, 11). O artigo 170, da Constituição Federal, que dispõe que a ordem econômica deve respeitar a defesa do consumidor, serve de fundamento mais geral ao pleito. Além disso, o seu artigo 5º, inciso XXXII, alçou a proteção do consumidor ao patamar de garantia fundamental individual e coletiva ${ }^{22}$. Com relação à legislação infraconstitucional, são citados diversos artigos do Código de Defesa do Consumidor, entre os quais os artigos 51 e 84, este último combinado com o disposto no artigo 273 do Código do Processo Civil, com o que se fundamentou o pedido de liminar, alegando-se "despro- 
porção contratual" e "locupletação indevida com os pagamentos dos financiamentos atrelados ao dólar" (Processo III, 4285 e ss.).

A fim de fundamentar sua tese, a ANACONT mobiliza o artigo $4^{\circ}$, inciso I, do Código de Defesa do Consumidor, que "reconhece a vulnerabilidade do consumidor no mercado de consumo", e que tem por objetivo o "equilíbrio contratual, igualando as partes tratantes na relação de consumo" (Processo III, 12). Em seguida, invoca o artigo 6o ${ }^{\circ}$, inciso V, do mesmo estatuto, que prevê a possibilidade de "modificação e revisão de cláusulas contratuais que criem prestações desproporcionais ou que venham a colocar o consumidor em desvantagem exagerada". A isso, a doutrina vem chamando de "dirigismo contratual", que faculta ao juiz a possibilidade de interferir no contrato, em nome da eqüidade, em uma clara evidência da crescente discricionariedade que vem sendo conferida ao juiz na condução do processo ${ }^{23}$. A favor do argumento, o artigo 51, IV, também é explícito, estabelecendo que "são nulas as cláusulas contratuais que estabeleçam obrigações consideradas iníquas, abusivas, que coloquem o consumidor em desvantagem exagerada, ou seja, incompatíveis com a boa-fé ou a eqüidade".

Mobiliza, ainda, a jurisprudência, sobretudo no que se refere aos efeitos produzidos por mudanças na política econômica sobre os consumidores. E mais especificamente, contra a "teoria da imprevisão", considerada superada em várias decisões tomadas pelo Superior Tribunal de Justiça, o que também significa a vitória da flexibilização da interpretação do contrato, como no exemplo a seguir, extraído de decisão desse Tribunal a respeito de contrato de aluguel: "Não é possível apego inflexível ao pacta sunt servanda no contexto da instabilidade da economia, ocasionando oscilação diária dos preços, urge voltar a atuação da cláusula rebus sic standibus. Não se tolera que um dos contratantes aufira lucro, apegando-se ao sentido literal da norma formalizada" (Processo III, 4285 e ss.).

Em seu pedido, a ANACONT solicita a antecipação de tutela para que a ré "abstenha-se de cobrar a variação cambial incidida sobre as prestações correspondentes ao contrato de leasing celebrado, retroativamente, a janeiro de 1999". Solicita, ainda, que se utilize o Índice Nacional de Preços do Consumidor - INPC como referência para o reajuste das mensalidades (idem).

O Juiz da $2^{a}$ Vara de Falências e Concordatas da Comarca da Cidade do Rio de Janeiro deferiu o pedido de liminar e julgou procedente em par- 
te o processo. Em sua decisão, aceitou a argumentação da reclamante, deferindo a liminar

"[...] para que as rés abstenham-se de cobrar a variação cambial incidida sobre as prestações correspondentes ao contrato de leasing celebrado, retroativamente a janeiro de 1999, compelindo as rés [obrigação de fazer] a emitirem novas boletas bancárias para a quitação do débito dos consumidores que celebraram contrato com a correção cambial, incidindo o índice concernente a realidade inflacionária, qual seja, o INPC sobre as prestações vincendas até o julgamento final da presente demanda" (idem).

Diante dessa decisão, as rés ingressaram com agravo junto ao Tribunal de Justiça, que foi recusado, conforme a ementa proferida por um desembargador, que admite a legitimidade da autora e refuta a tese proposta pelos réus de que o conflito versava sobre política cambial - o que transferiria a competência da matéria para o Banco Central e para a justiça federal -, sustentando que o conflito versava sobre relações de consumo, sendo, portanto, de competência estadual. Acrescenta, ainda, que "as instituições que oferecem crédito, em qualquer modalidade, estão sujeitas ao Código de Defesa do Consumidor". Em seguida, mobiliza o artigo 51, inciso IV desse Código, para advertir "que não é permitido que, de nenhuma forma, o risco de perda seja passado ao consumidor, por inteiro, como se pretende, em decorrência da variação do dólar, nem se admite que fique em desvantagem exagerada frente ao outro contratante". Finalmente, o desembargador elogia a decisão do juiz, que antecipou a tutela, sustentando que se trata de uma das mais marcantes em defesa e proteção do consumidor, e que merece ser mantida até o julgamento final da causa" (idem).

Conforme documentado no processo, após a decisão do Tribunal de Justiça quanto ao agravo, ainda seria tentado um acordo entre as partes, através de uma audiência especial, chegando a ser estabelecida uma comissão integrada pelos diversos interessados no assunto, a fim de "encontrar uma solução amigável para a questão". Mas os esforços fracassaram, e o desfecho foi a interposição de diversos agravos contra a decisão liminar.

Em linhas gerais, foram esses os principais argumentos dos agravantes: ilegitimidade do pleito; inaplicabilidade do Código de Defesa do Consumidor para os contratos de leasing; ilegitimidade das entidades defensoras de interesses de consumidores para propor ação coletiva; 
inaplicabilidade da teoria da imprevisão e defesa do princípio do pacta sunt servanda; incompetência do juízo.

Na decisão do mérito, o juiz desqualifica, um a um, esses argumentos. Com relação à incompetência do juízo, alega existir "remançosa jurisprudência, inclusive no Superior Tribunal de Justiça, em hipótese análoga, quando do Plano Verão e também do confisco da poupança", invocando, ainda, o "aresto paradigma", fundada em decisão de ministro do STJ, que sustentou em recurso especial de 1992, que "eventuais alterações na política econômica não afastam por si só a legitimidade ad causam das partes envolvidas em contratos de direito privado [...]" (idem).

Quanto à legitimidade da autora, mobiliza o artigo $1^{\circ}$, inciso II, combinado com o artigo $5^{\circ}$ da Lei $n^{\circ} 7.347 / 85$, que prevê que os danos ao consumidor podem ser reparados através das Ações Civis Públicas, e que as associações podem propor essas ações. No que se refere à legitimidade do pleito, mobiliza os artigos $4^{\circ}$, inciso I e $6^{\circ}$, inciso V do Código de Defesa do Consumidor para sustentar que "o diploma legal permite que o julgador possa modificar as cláusulas contratuais que estabeleçam prestações desproporcionais". E quanto à inaplicabilidade da teoria da imprevisão, sustentou que "o antigo princípio do pacta sunt servanda do Direito Romano merece nova interpretação, em consonância com os tempos modernos e com as diretrizes traçadas pelo Código de Defesa do Consumidor", e que a liminar "apenas considerou outro índice existente na legislação para ser aplicado aos contratos de leasing" (idem). Finalmente, sobre a inaplicabilidade do Código de Defesa do Consumidor ao caso, observa que, em seu artigo $3^{\circ}$, $§ 2$, é considerado serviço "qualquer atividade fornecida no mercado de consumo, mediante remuneração, inclusive as de natureza bancária, financeira, de crédito e securitária".

Levando-se em conta todos esses aspectos, o juiz estrutura sua decisão favorável, lembrando que o processo resultou em 21 volumes, com 4.270 páginas, "todas lidas". Sublinha, uma vez mais, que o artigo $3^{\circ}$, $\S$ 2 o do Código de Defesa do Consumidor estabelece que os "serviços fornecidos no mercado de consumo, mediante remuneração de natureza bancária, financeira e de crédito estão submetidas ao crivo do $C D C^{\prime \prime}, \mathrm{e}$ que o artigo 29 do mesmo diploma legal "equipara a consumidores todas as pessoas determináveis ou não, expostas às práticas previstas na legislação consumerista" (idem). Para dar sustentação a essa interpre- 
tação, recorre à jurisprudência firmada em casos anteriores - como na decisão do juiz José Carlos Varanda dos Santos, quando afirmou ser "incontroverso que no leasing financeiro nada mais há que a concessão de crédito, com o estabelecimento de uma garantia sem igual" -, bem como à doutrina, como "a lição de Claudia Lima Marques, que defende que 'o contrato de leasing', regulado como arrendamento mercantil, está sendo utilizado como contrato de consumo simples de pessoas físicas [...]" (idem). Cita, ainda, "aresto paradigma que tão bem examinou todas as questões discutidas nestes autos, e que teve por relator o Desembargador Sergio Cavalieri Filho". Entre outros aspectos, importa destacar da decisão do citado desembargador, afirma o juiz, que o "reajuste pela variação cambial do dólar viola os princípios da transparência, da confiança e da boa-fé objetiva".

Daí, conclui o juiz que, "violando o princípio da transparência", firmado em jurisprudência, a "cláusula prevendo o reajuste em dólar deve ser considerada como não escrita", e julga parcialmente procedente o pedido inicial para confirmar integralmente a liminar concedida, estabelecendo que "a formação da coisa julgada obedecerá às regras fixadas no artigo 103 e parágrafos do CDC, abrangendo, territorialmente, os limites da comarca da capital do Rio de Janeiro [conforme artigo 93, inciso II, do CDC]".

\section{IV.3 - A Efetividade da Ação}

Diversamente dos casos anteriormente analisados, este não tem como pólo passivo o poder público, não suscitando as questões típicas da cidadania política, que, por intermédio do Ministério Público, mobiliza os direitos coletivos como via de participação na vida pública. Por envolver empresas e não o poder público, o caso do leasing mostra-se, de certo modo, menos complexo, já que o efeito produzido pela sentença judicial tende a ser imediato, inexistindo a margem de manobra com que conta o poder público. O que não impede, naturalmente, que as empresas rés derrotadas em $1^{\text {a }}$ instância se sirvam das diferentes alternativas disponíveis no processo civil para recorrerem às instâncias superiores, o que, aliás, irão fazer.

Não obstante, a ação do leasing é sempre lembrada como um marco na curta história das ações coletivas consumeristas, em especial porque permitiu que uma associação pudesse se voltar, sozinha, contra os segmentos mais poderosos da vida econômica nacional. Sendo assim, a 
efetividade dessa ação não se esgota nos efeitos produzidos pela decisão judicial, na medida em que ela já apresenta uma configuração importante para a estrutura democrática do país, pois, através dessa ação, fica evidente que o reformismo jurídico, desenvolvido sob a égide do microsistema das ações coletivas, cria uma arena de resistência da sociedade diante das empresas. Ademais, o êxito de uma ação como essa fortalece a presença direta das associações civis no cenário das ações coletivas, apontando para um horizonte de crescente afirmação desse ator na defesa dos interesses coletivos.

Com isso, e relembrando o dilema verificado nos EUA, pode-se apostar que as duas vertentes que hoje caracterizam a defesa coletiva na área do consumidor naquele país também venham a se afirmar entre nós. Pois, se é verdade que, entre nós, o baixo êxito das ações coletivas promovidas por associações de consumidores não tem sido estimulante para que a arena dos direitos coletivos na área do consumidor se torne atraente para o mercado advocatício, nada impede que isso venha a ocorrer. De outro lado, o efeito-demonstração dos casos de sucesso, como o da ação do leasing, não deixa de advertir para o potencial do instrumento, introduzindo entre nós algo do regulatory enforcement, que se verifica nos EUA.

\section{O CASO DA CONTRATAÇÃO IRREGULAR DE TRABALHADORES ATRAVÉS DE COOPERATIVA}

Trata-se de uma Ação Civil Pública, promovida pelo Ministério Público do Trabalho, contra cinco empresas de serviços médicos, que teriam praticado "contratação fraudulenta" junto a uma cooperativa de serviços. O Ministério Público do Trabalho foi mobilizado para o caso pelo Movimento dos Trabalhadores contra as Cooperativas de Mão-de-Obra, que é ligado ao sindicato de trabalhadores da saúde um dos segmentos onde tem sido mais freqüente a utilização fraudulenta das cooperativas.

Antes de tratar especificamente deste caso, é importante lembrar que a presença do Ministério Público do Trabalho no cenário das ações civis públicas somente se consolidará com a Lei Complementar no 75/93, que trata das atribuições do Ministério Público, especialmente em seu artigo 83, inciso III, que estabelece que compete a ele "promover a ação civil pública no âmbito da Justiça do Trabalho, para a defesa de interesses coletivos, quando desrespeitados os direitos sociais constitucional- 
mente garantidos". Desde então, o Ministério Público do Trabalho vem se afirmando como autor de ações coletivas, relacionadas ao meio ambiente do trabalho e aos direitos sociais dos trabalhadores ${ }^{24}$. Trata-se, aí, de um exemplo forte de como a judicialização das relações sociais consiste em claro indicador de perda de substância da vida associativa, no caso a dos sindicatos, até recentemente um forte protagonista da vida social brasileira, que, privados de poder de negociação, se vêem tangidos a se socorrer do Ministério Público em defesa dos seus interesses.

Por outro lado, os dados do cooperativismo no Brasil indicam um nítido crescimento das cooperativas de trabalho na década de 1990, as quais responderiam, em 2001, por cerca de 300 mil cooperados. De acordo com Rodrigo Carelli, esse universo seria em sua grande maioria composto de "trabalhadores sem o mínimo de proteção social, sem a garantia de direitos sociais constitucionalmente assegurados, e que podem estar sendo simplesmente intermediados por uma sociedade formalmente cooperativada, mas que não cumpre os princípios deste instituto" (2002:9). Não por acaso, essa ação das cooperativas fraudulentas é exemplar de um dos temas fortes do Ministério Público do Trabalho, e sua importância levou, inclusive, a que se criasse, no âmbito do Ministério Público do Trabalho da $2^{a}$ Região, um grupo de trabalho para tratar especificamente do assunto.

\section{V.1 - Antecedentes}

Como já se observou, esta Ação Civil Pública foi suscitada pela reclamação feita pelo Movimento dos Trabalhadores contra as Cooperativas de Mão-de-Obra que, segundo um dirigente da entidade entrevistado pela pesquisa, inclui vários sindicatos, e "nasceu em São Paulo, em 2001, quando se estudava o projeto de lei das cooperativas" ${ }^{25}$. Segundo ele, a lei, aprovada em 2001, "criou brechas para se fraudar a legislação trabalhista" (entrevista, abril de 2004). Ainda de acordo com esse dirigente, "dentro da área da saúde a contratação de pseudo-cooperativas é muito forte, porque são empresas sem vínculos empregatícios, que são contratadas como cooperativas" (idem).

O caminho que leva ao Ministério Público, ainda na versão desse entrevistado, inclui a Delegacia do Trabalho, onde acontece a fiscalização de trabalhadores sem carteira assinada. Com base na fiscalização realizada pela Delegacia do Trabalho, mobiliza-se o Ministério Público do 
Trabalho. Em geral, diz ele, o procedimento adotado é o seguinte: "o sindicato é o próprio fiscalizador. Antes mesmo do Ministério Público do Trabalho, o sindicato chama a cooperativa, o cooperativado e a empresa". Com a intermediação da Delegacia do Trabalho, "realiza-se uma mesa-redonda, na tentativa de se fazer um acordo sem processo judicial, mas com a garantia de que se obteria uma confissão por parte da empresa fraudadora. A confissão da fraude por parte da empresa servirá, mais tarde, de material para o Ministério Público" (idem).

Frustrado o acordo, aí sim mobiliza-se o Ministério Público do Trabalho, e nesse momento o sindicato se afasta da condução do processo, mas procura se manter informado sobre seu andamento. Nesse instante, ao que tudo indica, o sindicato passa a ter no Ministério Público do Trabalho uma instância capaz de representá-lo e de, em alguma medida, produzir resultados mais rápidos e eficazes com menor custo. "A cada 15 dias procuramos o MP".

O dirigente sindical entrevistado observou que a luta do movimento tem encontrado "eco" em diversas categorias de trabalhadores, lembrando que "há pedidos de 'kit', para categorias como a dos trabalhadores da construção civil, indústria têxtil, dentre outras". Por "kit", entenda-se um manual informando sobre como fazer as denúncias, e como acionar a Delegacia do Trabalho e o Ministério Público do Trabalho. A existência do "kit" é mais uma evidência da internalização do caminho das ações coletivas na lógica de ação ordinária dos sindicatos. De acordo com o que está registrado no processo dessa Ação Civil Pública, após receber a denúncia do Movimento dos Trabalhadores Contra as Cooperativas de Mão-de-Obra, o Ministério Público instaurou, ainda em 1999, dois inquéritos civis públicos para apurar o caso, e chegou a propor um Termo de Ajustamento de Conduta às empresas, que foi recusado, levando o Ministério Público do Trabalho ao ajuizamento da ação civil pública, em maio de 2000.

\section{V.2 - A Sustentação Jurídica do Pleito}

Um dos pilares da sustentação jurídica desse pleito é a discussão acerca da verdadeira natureza de uma cooperativa, e mais especificamente do que seria uma cooperativa de trabalho ou produção, aqui entendida como "sociedade de direito civil criada entre trabalhadores de uma mesma categoria, cuja finalidade é aprimorar as condições de trabalho dos associados, mediante elevação da remuneração e obtenção de van- 
tagens acessórias". Em outro trecho do processo, salienta-se que, nas cooperativas, os trabalhadores "são sócios de seus próprios negócios, tornando-se cotistas das cooperativas a que pertencem" (Processo $950 / 00,4)^{26}$.

De modo a respaldar a conceituação de cooperativa, o Ministério Público mobiliza a legislação pertinente, invocando, em primeiro lugar, o Decreto 22.239/32, que seria revogado mais tarde pelo Decreto 59/66, mas que já definia as cooperativas como "constituídas entre operários de uma determinada profissão ou ofício, ou de ofícios, vários de uma mesma classe". Em seguida, menciona a Lei no 5.764/71 que, em seu artigo 30, define "que celebram contrato de sociedade cooperativa as pessoas que reciprocamente se obrigam a contribuir com bens ou serviços para o exercício de uma atividade econômica, de proveito comum, sem objetivo de lucro". Finalmente, invoca a Lei 8.984/94, que "visando favorecer e fomentar o cooperativismo, criou o parágrafo único do artigo 442 da Consolidação das Leis do Trabalho (CLT), excluindo o vínculo empregatício entre a cooperativa e seus associados, assim como entre estes e os tomadores de serviços daquela" (Processo IV, 6).

Outro fator lembrado é o de que a relação entre o contratante e a cooperativa é caracterizada pela impessoalidade, levando a que o Ministério Público do Trabalho busque respaldo em jurisprudência firmada pelo Tribunal Superior do Trabalho, no Enunciado 331, que cuida da questão da terceirização, ou seja, da contratação de serviços mediante a intermediação de outra entidade. A importância do Enunciado 331 para essa peça processual reside no fato de que, com base nele, "admite-se a exclusão do vínculo empregatício apenas em atividades-meio do tomador de serviços", incluindo as citadas atividades de segurança, conservação e limpeza, "desde que inexistentes a pessoalidade e a subordinação direta". Em seguida, o Ministério Público do Trabalho cita, em favor de seu argumento, a sentença do juiz Marcel da Costa Roman Bispo, da Junta de Conciliação e Justiça de Magé, que afirma que: "assistimos, atônitos, a proliferação de cooperativas e prestadoras de serviços que são meras intermediárias, verdadeiros biombos institucionais que só servem para mascarar relações de trabalho subordinado. O seu lucro é obtido na razão direta da subtração dos direitos sociais dos trabalhadores".

É com base nessa articulação entre a legislação e a jurisprudência que tratam das cooperativas que o Ministério Público do Trabalho sustenta 
que: "ao contrário daquilo que vislumbrou o legislador e o judiciário trabalhista, o que se verificou no presente caso foi a prestação de serviços de forma que se torna inafastável a caracterização da relação de emprego, estando presente todos os seus requisitos: habitualidade, onerosidade, pessoalidade e subordinação" (Processo IV, 9).

E conclui: "Admitidos e dispensados individualmente (pessoalidade), submetidos a horários determinados pelas empresas tomadoras de serviços, agindo conforme suas diretrizes (subordinação), de modo habitual (não eventual), os 'cooperados' são, na verdade, empregados, prestando serviços às empresas ávidas por aumentarem suas margens de lucro mediante a fraude aos direitos sociais dos trabalhadores" (idem).

Antes de explicitar o pedido do Ministério Público do Trabalho, é válido lembrar sua argumentação com vistas a sustentar a sua legitimidade para pleitear ações civis públicas. A par de invocar a já citada Lei Complementar 75/93, "que legitimou definitivamente o Ministério Público do Trabalho a utilizar-se da ação civil pública para a defesa de interesses coletivos e difusos", também mobiliza a doutrina e a jurisprudência existentes sobre a questão. De trabalho de doutrina de Ives Gandra da Silva Martins Filho, extrai uma boa definição sobre a divisão de competência existente entre o Ministério Público do Trabalho e os sindicatos: "o sindicato defende os trabalhadores que a ordem jurídica protege; e o Ministério Público defende a própria ordem jurídica protetora dos interesses coletivos dos trabalhadores" 27.

Essa delimitação é crucial, pois evidencia que entre o Ministério Público do Trabalho e o sindicato não existe necessariamente uma relação de usurpação de papéis do segundo pelo primeiro, apontando, antes, para uma relação de complementaridade. A própria delimitação precisa da legitimidade ativa do Ministério Público do Trabalho, no âmbito de ações coletivas, tem sido, como se verificará nesta ação, um fator importante para minimizar os riscos de possíveis efeitos substitutivos.

Em seguida, cita algumas decisões judiciais que confirmam como ponto pacífico a legitimidade do Ministério Público do Trabalho para pleitear Ações Civis Públicas.

Com base nessa argumentação é que vai formular o pedido de tutela antecipada, a fim de que seja imediatamente declarado o vínculo empregatício dos trabalhadores "cooperados" com as rés, "realizando-se 
registro dos empregados e anotação de suas carteiras de trabalho, além de pagamento de todos os encargos sociais desde a data real de admissão". Requer, ainda, que se proíba às rés de "contratar trabalhadores por via terceirizada em sua atividade-fim", bem como "contratar trabalhadores por cooperativas intermediadoras de mão-de-obra" (Processo IV, 19 e ss.).

\section{V.3 - A Construção da Decisão}

Antes de tomar qualquer decisão, o juiz da $58^{a}$ Vara do Trabalho convocou, em agosto de 2000, uma audiência com as partes. Na oportunidade, as rés apresentaram sua defesa, baseada, entre outros, nos seguintes pontos: que a concessão de liminar "levaria de imediato à perda de inúmeros postos de trabalho"; que "a terceirização é uma realidade, e a jurisprudência a vem reconhecendo"; que o Ministério Público do Trabalho é "parte ilegítima"; e que os cooperados "não estavam subordinados a qualquer poder diretivo, disciplinar ou fiscalizador do contratante".

Com base nesses pontos, as empresas acusadas pediram a improcedência da causa, recusando a conciliação. Diante disso, não coube ao juiz outra alternativa se não a de decidir. Em sua fundamentação, o juiz começa por reagir ao questionamento quanto à legitimidade do Ministério Público do Trabalho, estabelecendo que "ao contrário do que alegam as reclamadas, o interesse envolvido nesta ação não é apenas pessoal, mensurável e identificável", o que o descaracterizaria enquanto direito difuso e coletivo. Ao contrário, afirma o juiz, quando está pleiteando que se proíba as empresas rés de terceirizar atividades-fim, bem como de contratar trabalhadores por cooperativas intermediadoras de mão-de-obra, o Ministério Público do Trabalho está postulando por direitos de trabalhadores que sequer podem ser identificados, "muito menos que os direitos que acaso lhes caibam sejam perfeitamente identificáveis, divisíveis e mensuráveis". Trata-se, pois, conclui o juiz, "de direito coletivo e difuso, cujos titulares não podem ser identificados" (Processo IV, 245).

Essa interpretação do juiz acerca da questão da legitimidade do Ministério Público do Trabalho para postular ações civis públicas evidencia a complexidade da matéria. Em entrevista realizada pela equipe da pesquisa, o procurador responsável por este caso observou que esse processo trazia uma novidade importante na estratégia utilizada pelo 
Ministério Público do Trabalho ao colocar no foco não as cooperativas, mas as empresas contratantes, o que viabilizou a argumentação de que não se está defendendo uma categoria definida de trabalhadores, mas um princípio da ordem jurídica. A esse respeito, o juiz irá se manifestar nos seguintes termos:
“[...] se o parque estivesse demandando contra os próprios cooperados
[...] a hipótese seria de impossibilidade jurídica, porque não se pode es- tar ao mesmo tempo como réu e autor no mesmo pedido. Mas os traba- lhadores substituídos não são réus nesta ação; e os interesses dos mes- mos nela defendidos são interesses indisponíveis quanto aos que já se acham trabalhando [reconhecimento de vínculo], além de coletivos e difusos quanto aos que possam vir a ser contratados [...]" (idem:242).

Aliás, é por essa mesma razão que, conforme veremos adiante, o juiz não irá acolher a parte do pedido do Ministério Público do Trabalho que se refere especificamente aos trabalhadores contratados pela empresa através da cooperativa, pois, embora reconhecendo haver vínculo de emprego entre as reclamadas e os trabalhadores, "não é o Ministério Público do Trabalho parte legítima para postular a favor dos trabalhadores, nesta ação, o pagamento de direitos sociais" (idem:253).

Seguindo a linha de argumentação do juiz, na fundamentação de sua decisão, observa-se que após refutar a tese da ilegitimidade do Ministério Público do Trabalho, entra na discussão do mérito da questão, rejeitando a interpretação adotada pelas rés quanto ao artigo 442 da CLT, que, convém lembrar, estabelece que, "qualquer que seja o ramo da atividade da sociedade cooperativa, não existe vínculo empregatício entre ela e seus associados, nem entre estes e os tomadores de serviços daquela". Ora, replica o juiz: "não se cuida aqui da primeira parte, vínculo entre cooperativas e cooperados, e sim do vínculo entre cooperados e tomadores de serviços das cooperativas. A lei, invocada tão repetidamente pelas reclamadas, apenas considera a inexistência de vínculo com tomadores de serviços; nenhuma menção faz à relação que se estabelece com cooperados que individualmente forneçam trabalho" (ibidem).

E antecipando sua decisão quanto ao mérito da questão, o juiz afirma: "o que se evidencia nestes autos é o abuso de uma das mais fecundas instituições sócio-jurídicas de nossos tempos, o sistema cooperativo, para propiciar o acobertamento de contratação ilegal de mão-de-obra por empresas, para atendimento de sua atividade-fim, com isso lesando direitos trabalhistas de trabalhadores" (ibidem). 
Após apresentar suas razões, o juiz decide na sentença o mérito e o pedido de tutela antecipada. Defere em parte a tutela antecipada requerida, "para que as reclamadas se abstenham de contratar trabalhadores para sua atividade-fim sob capa de terceirização", e julga procedente em parte a ação "para declarar existente o vínculo de emprego entre as reclamadas e os trabalhadores que estavam em atividade na data em que foi ajuizada esta ação, e os que admitidos forem até que produza efeitos a decisão que as impede de continuar contratando nas mesmas condições" (Processo IV, 254). Portanto, embora a decisão não produza o efeito retroativo postulado pelo Ministério Público do Trabalho, assegura que a prática da contratação de trabalhadores cooperativados para a realização de atividades-fim não mais prosperará, senão na clandestinidade. A natureza abstrata da decisão, que não se aplica aos trabalhadores concretamente envolvidos, mas aos "trabalhadores em geral", funciona, portanto, como um novo e poderoso paradigma jurídico, importando, de fato, na criação de direito, interditando uma das práticas fraudulentas que, freqüentemente, vem sendo adotada pelas empresas, interessadas em diminuir seus custos com o trabalhador.

Em março de 2001, as empresas rés entraram com recurso ordinário ( $\mathrm{n}^{\mathrm{o}}$ 14.152/01) junto ao Tribunal Regional do Trabalho da $1^{\text {a }}$ Região, argüindo, na preliminar, a ilegitimidade do Ministério Público do Trabalho para "defender direitos individuais homogêneos"; e no mérito, a ausência de "razão fática, a provar a existência de simulação, fraude ou coação, na admissão dos trabalhadores nas cooperativas contratadas pelos recorrentes" (Processo IV, 321), a inexistência de "qualquer vínculo empregatício entre os cooperativados e o tomador de serviços", e, ainda, a "inexistência de base legal a impedir a relação de trabalho entre cooperativas de trabalho e as recorrentes" (Processo IV, 322). Contra essa argüição, o Ministério Público do Trabalho reiterou sua fundamentação já apresentada na inicial do processo, apenas ampliando sua base de sustentação argumentativa através da mobilização de doutrinadores não citados anteriormente, bem como de farta jurisprudência, tanto para afirmar a legitimidade do Ministério Público do Trabalho para atuar nesse tipo de caso, quanto no que se refere ao mérito da questão, reiterando que: “É inegável a ilegalidade da terceirização em atividade-fim, conforme o Enunciado 331 do TST. E a fraude de direitos trabalhistas pela intermediação de mão-de-obra cooperada é também objeto de repúdio de todos os doutrinadores respeitáveis do direito trabalhista" (MPT, Recurso Ordinário no 14.152/01). 
Em decisão tomada em dezembro de 2001, a $4^{\mathrm{a}}$ Turma do Tribunal Regional do Trabalho da $1^{a}$ Região, por unanimidade, rejeita as preliminares e, no mérito, nega provimento ao recurso, prolatando o seguinte acórdão:

"O uso de cooperativas de trabalho, de forma ampla e irrestrita, aponta para a existência de tentativa de fraudar a legislação trabalhista, particularmente se não se separa a atividade-meio e atividade-fim das reclamadas, na contratação desta mão-de-obra, os prazos dos contratos são por tempo indeterminado e existe pagamento de percentual à cooperativa sobre o valor pago aos cooperativados. A prova a afastar tal presunção há que ser robustamente demonstrada [...]" (TRT da $1^{a}$ Região, 4ª Turma, Acórdão/Recurso Ordinário no 14.152/01).

Contra a decisão tomada pelo Tribunal Regional do Trabalho em face do Recurso Ordinário, as empresas reclamadas ainda vão interpor embargos de declaração, alegando que houve "omissão no Acórdão", ao deixar de "fundamentar a tese de que o Ministério Público do Trabalho poderia ajuizar Ação Civil Pública para defender interesses individuais homogêneos"; por não "justificar o reconhecimento de vínculo deferido"; e por não "definir os critérios objetivos para identificação da contratação a que estão vedados os embargantes quando da contratação de cooperativas".

Os três embargos foram refutados por unanimidade pela $4^{\mathrm{a}}$ Turma do Tribunal Regional do Trabalho da $1^{\text {a }}$ Região, em novembro de 2002. O primeiro, por se considerar suficiente as razões apresentadas no acórdão para justificar a legitimidade do Ministério Público do Trabalho para atuar na questão; o segundo, por entender que "a matéria foi esgotada no Recurso Ordinário com a aplicação do Enunciado 331"; e o terceiro, por se entender que não houve "omissão ou contradição, ficando claro o entendimento de que o uso de cooperativas de trabalho, para as atividades-fim das empresas, encontrará sempre forte resistência nesta Justiça Especializada" (Recurso Ordinário noำ 14.152/01, Embargos de Declaração).

\section{V.4 - A Efetividade da Ação}

Com base na documentação levantada, constata-se que, desde dezembro de 2002, o Ministério Público do Trabalho vem monitorando a execução da decisão transitada em julgado, que parece estar sendo objeto de muita resistência por parte das empresas rés. Algum tempo depois, 
inclusive, uma das empresas fraudadoras foi desfeita, obrigando-o, já em março de 2004, a requerer junto ao juiz da $58^{a}$ Vara, a suspensão da execução quanto a esta empresa, "sendo que, se porventura a referida executada, para burlar a sentença, montar outra empresa, para continuar a atividade econômica com trabalhadores de forma irregular, requererá o MP a reabertura da execução". Os limites da atuação do Ministério Público do Trabalho no acompanhamento do caso evidenciam, mais uma vez, que ele - nesse, como nos demais casos - não pode prescindir da parceria com a sociedade civil organizada. Dessa parceria depende, afinal, a maior ou menor efetividade das ações coletivas.

Mas a análise da efetividade da ação em questão também demanda que se reflita sobre seu efeito propriamente jurídico, ou seja, sua repercussão na construção coletiva do direito. Nesse sentido, o aspecto mais importante a ser considerado diz respeito ao efeito erga omnes da decisão judicial. Ainda que limitada à circunscrição do Tribunal Regional do Trabalho da $1^{a}$ Região, essa decisão introduz uma importante tensão na tendência atual do mercado de trabalho de desconsiderar os direitos do trabalhador previstos em lei. O estudo deste caso, a exemplo do que já se verificara no caso da ação do leasing, evidencia o potencial da Ação Civil Pública enquanto instrumento de elaboração de uma argumentação inovadora a respeito dos direitos constitucionais e infraconstitucionais, voltada para a defesa dos direitos sociais em face da lógica mercantil.

É por isso que a efetividade de ações como a acima analisada ultrapassa em muito seu efeito imediato sobre o conflito concreto, servindo como referência jurídica e política de articulação da sociedade organizada com o direito e com suas instituições ${ }^{28}$.

(Recebido para publicação em maio de 2005) (Versão definitiva em novembro de 2005) 


\section{NOTAS}

1. Com isso, verificou-se uma melhor aferição da vontade do eleitor e, desde a implementação da urna eletrônica, uma sensível redução do número de votos brancos e nulos, que, com a cédula de papel, chegou a atingir o percentual de $43 \%$ em eleição para Câmara de Deputados, vindo a baixar para 8\% na disputa de 2002 (Nicolau, 2003).

2. A Lei $n^{0} 9.840$ resultou de uma intensa mobilização popular, reunindo mais de 1 milhão de assinaturas de eleitores, reivindicando eleições sem fraudes e sem abuso do poder econômico. De acordo com essa lei, a Justiça Eleitoral pode cassar o registro dos candidatos que tentarem comprar o voto dos eleitores.

3. O juiz Márlon Jacinto Reis, da 11 $1^{a}$ Zona Eleitoral do Maranhão, foi merecedor do Prêmio Innovare - concurso nacional para premiação de práticas inovadoras no âmbito do Poder Judiciário, patrocinado pela Associação dos Magistrados Brasileiros, pelo Ministério da Justiça, pela Fundação Getulio Vargas e pela Companhia Vale do Rio Doce - por ter aplicado esse diploma legal, obtendo resultados importantes no combate à corrupção eleitoral.

4. No desenvolvimento desse argumento, acompanha-se a análise realizada no texto supracitado.

5. Dezenas de juízes, no concurso Prêmio Innovare, relataram práticas da sua magistratura em que tal papel substitutivo é evidente.

6. Em Cittadino (1999), a melhor análise sobre a presença do comunitarismo como um valor na Carta de 1988.

7. O CDC, em seu artigo 113, parágrafo 6º definiu que o Ministério Publico, entre outros órgãos legitimados, poderá "tomar dos interessados compromisso de ajustamento de sua conduta às exigências legais, mediante cominações, que terá eficácia de título extrajudicial”. Em conseqüência, o Ministério Público irá se converter em uma arena complementar ao Judiciário, ora como ante-sala do processo judicial, ora como instância de resolução extrajudicial de conflitos (Werneck Vianna e Burgos, 2002).

8. Ver matéria jornalística de $O$ Globo, "Ações contra 16 empresas paralisam a Justiça no Rio", 1ํㅡㄹ agosto de 2004.

9. Ver o estudo de Luiz Fux (2000) e também as pesquisas quantitativas realizadas pelo Laboratório de Economia Política da Saúde - LEPS, da Universidade Federal do Rio de Janeiro - UFRJ, sobre a incidência de ações contra planos privados de saúde nos Tribunais de São Paulo e do Rio de Janeiro.

10. Uma importante discussão sobre a relação entre princípios e regras na jurisprudência constitucional do direito brasileiro atual está em Barroso e Barcellos (2003).

11. É importante frisar que, nos últimos anos, algumas emendas à Lei no $7.347 / 85$ têm sido aprovadas, visando limitar seu alcance. Exemplo disso é o parágrafo único acrescentado ao seu artigo $1^{\circ}$ pela Medida Provisória no 1.984/2000, que estabelece que não caberá Ação Civil Pública em matérias envolvendo tributos, contribuição previdenciária e Fundo de Garantia do Tempo de Serviço - FGTS, “cujos beneficiários podem ser individualmente determinados". Outro exemplo é a nova redação dada ao artigo 16, pela Lei no 9.494/1997, que limita o efeito erga omnes aos "limites da competência territorial do órgão prolator". 
12. Para facilitar a exposição, doravante este processo será caracterizado apenas como "Processo I".

13. Embora o fenômeno se apresente nos diferentes segmentos da vida pública nacional, na área de saúde a atuação do Judiciário na regulação dos serviços públicos e privados tem sido particularmente importante. A esse respeito, pesquisa recente do Laboratório de Economia Política da Saúde, da UFRJ, constatou que, entre janeiro de 2003 e setembro de 2004, nada menos que 611 recursos de agravos de instrumento, envolvendo processos movidos por consumidores contra planos de saúde, foram julgados pelos Tribunais de Justiça dos estados do Rio de Janeiro e de São Paulo, sendo que cerca de $80 \%$ dos casos contra decisões de $1^{\text {a }}$ instância favoráveis aos usuários (LEPS/UFRJ, 2004).

14. Doravante, este processo será denominado "Processo II".

15. Para a reconstrução dessa trajetória, ver Sierra (2004).

16. Cabe lembrar que o Ministério Público já ingressou com duas Ações Civis Públicas contra a prefeitura, relacionadas à estruturação adequada dos conselhos tutelares, e que ambas foram acolhidas pelo Judiciário.

17. Uma visita feita pela equipe da pesquisa, em setembro de 2004, a um dos locais, em Botafogo, comprovou o funcionamento do serviço.

18. Conforme observou um dos Procuradores da República entrevistado sobre o caso: "as ilhas, são um bem da União. Conforme decreto de 1946, as ilhas costeiras e demais ilhas são patrimônio da União. Ao mesmo tempo em que as reservas são todas estaduais, ficando por conta do IEF e da FEEMA. [...] A questão ambiental na Ilha Grande é mais relevante ainda porque é uma área que faz parte do patrimônio histórico-cultural nacional" (entrevista, maio de 2004).

19. Doravante, identificado como "Processo III".

20. Programa de Defesa do Consumidor, que existe em quase todas as principais cidades brasileiras, em geral subordinado ao Poder Executivo municipal ou estadual.

21. De acordo com Castro Mendes (2002:191 e ss.), a lei do meio ambiente e a lei orgânica do Ministério Público, aprovadas em 1981, fortaleceram o debate em torno da questão dos direitos coletivos, dando ensejo à formação de um grupo de juristas de São Paulo, ligados à Universidade de São Paulo - USP, que empreendeu um primeiro anteprojeto de lei de Ação Civil Pública. Ao mesmo tempo, um grupo de promotores de justiça, também de São Paulo, elaborava um outro anteprojeto de lei.

22. "O Estado promoverá, na forma da lei, a defesa do consumidor" (Constituição Federal, art. 5o, inciso XXXII).

23. Este é um dos pontos que apontariam para a convergência entre as duas principais "famílias jurídicas" do ocidente, a civil law e a common law (Cappelletti, 1993).

24. Em levantamento por nós realizado em 2001, junto ao Tribunal Regional do Trabalho da 1ํㅡ Região/Seção do Rio de Janeiro, constatamos que o Ministério Público do Trabalho respondia por cerca de $70 \%$ das ações civis públicas propostas naquele tribunal, ficando os $30 \%$ restantes a cargo dos sindicatos.

25. O dirigente entrevistado pela pesquisa é advogado do Sindicato dos Trabalhadores da Saúde de Estabelecimentos Privados da Baixada Fluminense, categoria basicamente composta "por auxiliares de enfermagem, enfermeiros e técnicos de enfermagem" (entrevista, abril de 2004). 
26. Doravante denominado "Processo IV".

27. Trecho extraído de Ives Gandra S. M. Filho (1996).

28. Uma contribuição importante a esse debate é a recente tese de Paulo Guilherme Périssé (2004), que discute o potencial das Ações Civis Públicas trabalhistas na reestruturação da relação entre as instituições do direito e o mundo do trabalho, isto é, como instância de defesa da cidadania dos trabalhadores.

\section{REFERÊNCIAS BIBLIOGRÁFICAS}

BARROSO, Luiz Roberto e BARCELLOS, Ana Paula de. (2003), “O Começo da História. A Nova Interpretação Constitucional e o Papel dos Princípios no Direito Brasileiro", in L. R. Barroso (org.), A Nova Interpretação Constitucional. Rio de Janeiro/São Paulo, Editora Renovar.

CAPPELLETTI, Mauro. (1993), Juízes Legisladores?. Porto Alegre, Sergio Antonio Fabris Editor.

CARELLI, Rodrigo de Lacerda. (2002), Cooperativas de Mão-de-Obra. Manual Contra a Fraude. São Paulo, Editora LTr.

CITTADINO, Gisele. (1999), Pluralismo, Direito e Justiça Distributiva. Elementos da Filosofia Constitucional Contemporânea. Rio de Janeiro, Lumen Juris.

FILOMENO, José Geraldo Brito. (2001), “Ação Civil Pública Consumerista”, in É. Milaré (coord.), Ação Civil Pública - Lei 7.347 -15 Anos. São Paulo, Editora Revista dos Tribunais.

FUX, Luiz. (2000), Tutela de Urgência e Plano de Saúde. Rio de Janeiro, Espaço Jurídico.

GARAPON, Antoine. (1996), Le Gardien de Promesses. Paris, Odile Jacob.

GRINOVER, Ada Pellegrini. (2001), “Da Class Action for Damages à Ação de Classe Brasileira. Os Requisitos de admissibilidade", in É. Milaré (coord.), Ação Civil PúblicaLei 7.347 - 15 Anos. São Paulo, Editora Revista dos Tribunais.

HENSLER, Deborah R. et alii. (2000), Class Action Dilemmas: Pursuing Public Goals for Private Gain. Santa Monica, CA, RAND Institute for Civil Justice.

LABORATÓRIO DE ECONOMIA POLÍTICA DA SAÚDE/UFRJ. (2004), Planos e Seguros de Saúde e Efetividade da Justiça. Rio de Janeiro, UFRJ. Manuscrito.

MANCUSO, Rodolfo. (2001), “A Ação Civil Pública como Instrumento de Controle das Chamadas Políticas Públicas", in É. Milaré (coord.), Ação Civil Pública - Lei 7.347 - 15 Anos. São Paulo, Editora Revista dos Tribunais.

MARTINS FILHO, Ives Gandra. (1996), Processo Coletivo do Trabalho (2ª ed.). São Paulo, Editora LTr, pp. 209-210. 


\section{Luiz Werneck Vianna e Marcelo Baumann Burgos}

MENDES, Aluisio Gonçalves de Castro. (2002), Ações Coletivas no Direito Comparado e Nacional. São Paulo, Editora Revista dos Tribunais.

NICOLAU, Jairo. (2003), "A Participação Eleitoral no Brasil”, in L. Werneck Vianna (org.), A Democracia e os Três Poderes no Brasil. Belo Horizonte, Editora da UFMG.

PÉRISSÉ, Paulo Guilherme. (2004), O Sindicalismo Brasileiro em Transformação - A Ação Civil Pública como Estratégia de Ação. Dissertação de Mestrado, Iuperj, Rio de Janeiro.

ROSANVALLON, Pierre. (2000), La Démocratie Inachevée. Paris. Éditions Gallimard.

SIERRA, Vânia Morales. (2004), A Judicialização da Infância. Tese de Doutorado, Iuperj, Rio de Janeiro.

WERNECK VIANNA, Luiz. (2002), “Apresentação”, in L. Werneck Vianna (org.), A Democracia e os Três Poderes no Brasil. Belo Horizonte, Editora da UFMG.

e BURGOS, Marcelo Baumann. (2002), “Revolução Processual do Direito e Democracia Progressiva", in L. Werneck Vianna (org.), A Democracia e os Três Poderes no Brasil. Belo Horizonte, Editora da UFMG.

WERNECK VIANNA, Luiz, CARVALHO, Maria Alice Rezende de, MELO, Manuel Palácios Cunha e BURGOS, Marcelo Baumann. (1999), Judicialização da Política e das Relações Sociais no Brasil. Rio de Janeiro, Revan. 


\begin{abstract}
Principles and Rules: Five Case Studies of Class Action Suits in Brazil

This article presents case studies of class action suits in the areas of consumer rights, childhood, the environment, health, and work. The study is based on process analysis and interviews with the respective parties to the suits. The results provide a better understanding of the dynamics of new areas of conflict and the affirmation of collective rights through interaction between civil society and legal institutions like the Office of the Public Defender, Office of the Public Prosecutor, and Judiciary Branch as a whole.
\end{abstract}

Key words: Class action; law; citizenship; social conflict and judicial power; brazilian democracy

\title{
RÉSUMÉ
}

Entre Principes et Règles: Cinq Études de Cas d'Action Civile Publique

Dans cet article, on trouve l'étude de cinq études de cas d'actions civiles publiques qui traitent des droits collectifs et diffus dans les domaines de la consommation, de l'enfance, de l'environnement, de la santé et du travail. L'étude se fonde sur l'analyse de dossiers et d'entretiens avec les parties concernées directement et indirectement dans chaque cas. Les résultats obtenus dans la recherche permettent de mieux comprendre la dynamique des nouveaux théâtres de conflit et d'affirmation des droits qui se construisent à partir de l'interaction entre la société civile et les institutions du Droit, comme les Avocats Généraux, le Ministère Public et le Pouvoir Judiciaire.

Mots-clé: action civile publique; droit; citoyenité; théâtres de conflit; démocratie brésiliene 